\title{
JANKOVICHIAN, SZELETIAN OR A LEAF POINT INDUSTRY: ANALYSIS OF THREE SMALL LITHIC ASSEMBLAGES
}

\author{
ANDRÁS MARKÓ \\ Department of Archaeology, Hungarian National Museum \\ 14-16, Múzeum körút, H-1088 Budapest, Hungary \\ markoa@hnm.hu
}

'The duty of the man who investigates the writings of scientists, if learning the truth is his goal, is to make himself an enemy of all that he reads, and [...] attack it from every side. He should also suspect himself as he performs his critical examination of it, so that he may avoid falling into either prejudice or leniency.' (Alhazen)

\begin{abstract}
The eponymous site of the Jankovichian industry was found at the Öreg kö cliff, in the northern part of the Transdanubia, Western Hungary. From the thick layer complex of the Jankovich cave, however, only 104 lithics were collected and the scarce data showed that the pieces belong to several archaeological entities. At the same time, the nearly total lack of the field documentation allowed the reconstruction of the stratigraphic position of each artefact only in a few cases. The stratigraphic integrity is missing from the archaeological material of the Kiskevély and Szelim caves as well as the Csákvár rock shelter, and according to the recent evaluations the bifacial tools from the Dzeravá skála (Pálffy cave) and Lovas belong to the Micoquian and the Late Palaeolithic period.

In this paper we analyse the following three assemblages, excavated after World War II in Transdanubia: the Pilisszántó rock shelter II, the Bivak and the Remete Felsö caves. The chronological, basically, bio-stratigraphic data known from these layers are also evaluated.

The conclusion of the study is that (1) the chronological data of the studied sites do not permit to place the archaeological occupation of each cave into the Early Würm or to the Late Middle Palaeolithic period and (2) the validity of a distinct Jankovichian industry cannot be proved.
\end{abstract}

Keywords: Jankovichian, Szeletian, chronology, leaf shaped tool

The eponymous site of the Szeletian industry is located in the eastern part of the Bükk Mountains in Northeastern Hungary. However, as the recent analysis showed none of the assemblages excavated in 'fireplaces' or 'culture layers' in the Szeleta cave can be classified as belonging to the Szeletian industry itself.' In fact, this problem can be traced back to the definition of the Szeletian ${ }^{2}$ and it was emphasised several times by specialists having direct information on the Szeleta assemblages. ${ }^{3}$

Recently this term has been used, even if on an informal way, for various industries not only from Slovakia, Moravia, Poland and Bavaria, but also from a vast territory lying between the Rhine Valley and the Don Basin, ${ }^{4}$ and from Poland to the Balkans. ${ }^{5}$ At the same time, the 'eastern Szeletian' assemblage of Buran-kaya III in the Crimea was excavated beneath the Micoquian layers, ${ }^{6}$ illustrating that the 'Szeletian' plays exactly the same role as the 'Solutréan' before 1953: connecting very different industries having a single common trait, namely the presence of leaf shaped implements.

${ }^{1}$ Markó 2016, 32.
${ }^{2}$ ProšEK 1953.
${ }^{3}$ For instance: GÁBORI-CsÁnK 1956; FreUnd 1968 GÁBORI 1968; VÉRTES 1968.
${ }^{4}$ Patou-Mathis 2000, 386, 392; Zaliznyak-Belenko 2009.

\footnotetext{
${ }^{5}$ For instance: FolTyn 2003; MiHAILOVIĆ-ZoRBić 2017.
}

${ }^{6}$ Marks-Monigal 2000, 217-218; Chabai 2003, 75; PÉAN et al. 2013. 
Even in Hungary, a number of different assemblages and finds are united under this term, including the industries of the Szeleta cave, ${ }^{7}$ the Szeletian industry as it was described by F. Prošek in $1953^{8}$ and the leaf shaped artefacts selected from the mixed surface collections. ${ }^{9}$ In the $1950 \mathrm{~s}^{10}$ two geographical groups of the Szeleta culture were differentiated in the Bükk Mountains and Transdanubia, respectively. As a result of the excavations in the Remete Upper cave (1969-1971) instead of this later Transdanubian group the Middle Palaeolithic Jankovichian industry was postulated. ${ }^{11}$ The definition of this new cultural entity, dated to the Early Würm ("Altwürm', MIS 5 d-a) by archaeological, paleontological and palaeo-botanical arguments was based on 176 lithic artefacts, collected from eight different localities in Hungary and one in Slovakia. However, the richest and eponymous site yielded only 104 lithics, most probably belonging to several different archaeological industries, excavated from the $6 \mathrm{~m}$ thick layer sequence and only at five pieces are the data on the exact place of the recovery available. ${ }^{12}$ The field observations are also absent from the Szelim ${ }^{13}$ and Kiskevély ${ }^{14}$ caves, excavated before the World War II. Similarly the history of the interpretation of the Csákvár rock shelter and the Lovas ochre mine locality are typical and instructive. During the palaeontological excavations of the Csákvár rock shelter in 1926 and 1928 a pierced deer canine and a human metacarpal bone was found in the Pleistocene light brown loam. ${ }^{15}$ In 1951 further artefacts and another human bone were collected from the back-dirt of the previous field works. ${ }^{16}$ The age of the rather atypical fauna was estimated to be more recent than the characteristic 'Würm I' assemblages but older than the 'Würm III' faunas (MIS 4 and MIS 2, respectively). ${ }^{17}$

Among the lithics collected in $1951 \mathrm{~L}$. Vértes compared a bifacially worked knife and a side scraper to the Mousterian tool types from Tata and he noted that a single flake with large bulb of percussion is similar to the blanks known from the Jankovich cave. ${ }^{18}$ This atypical piece was enumerated among the Jankovichian finds in the eighties $^{19}$ and in 1993 the artefacts identified earlier as Mousterian tools by Gábori-Csánk as well as two flakes were also listed among the lithics of the same industry. ${ }^{20}$ In our view, however, this new classification of the scattered finds from the Csákvár rock shelter is not convincing enough.

Similarly, the single leaf shaped scraper of limnic quartzite ${ }^{21}$ excavated at Lovas allowed to describe this locality as the only one open-air site of the Transdanubian Szeletian. Although in the 1970s and 1980s M. Gábori and V. Gábori-Csánk suggested, that the presence of a single typical tool was not sufficient to list the site among the Jankovich-type industry, ${ }^{22}$ in the monograph consecrated to this entity twelve flakes, a core fragment and a raw material fragment, each made of radiolarite were also enumerated among the Middle Palaeolithic artefacts ${ }^{23}$ and the single typical tool was compared to the earliest pieces of the industry known from the Kiskevély cave. ${ }^{24}$

${ }^{7}$ Importantly, the 'Szeletian culture' was originally defined as a typical Upper Palaeolithic industry with leaf points and strong Gravettian traits using the modern terminology (I. L. Červinka in 1927): PRoŠEK 1953, 145

${ }^{8}$ Mester 2017, 85, 86; Mester 2018, 34.

${ }^{9}$ Mester 2017, 87; Mester 2018, 34.

${ }^{10}$ Mészáros-Vértes $1954,19,25$, note 54 , Fig. 13 ; VÉRTES 1955a, 273-277.

${ }^{11}$ GÁBORI-CSÁNK 1974; GÁBORI-CSÁNK 1983; GÁborICSÁNK 1984; GÁBORI-CSÁNK 1990; GÁBORI-CSÁNK 1993; GÁBORI 1976, 78-80.

${ }^{12}$ MARKó 2013a, 11, 19-20. - The doubts foreshadowed but not expounded by Zs. Mester about the stratigraphic observations by the excavator of this site, ascertained in the publications and the inventory book are completely unfounded: MESTER 2017, 84; MESTER 2018, 34.c.f. HiLLEBRAND 1926; VÉRTES 1955a, 276

${ }^{13}$ According to Gábori-Csánk the excavation methods used on this site raised a number of problems: 'Sa fouille a été faite malheureusement selon une méthode particulièrement mauvaise.': GÁBORI-CSÁNK 1983, 279; cf. GÁBORI-CSÁNK 1984, 18.

${ }^{14}$ At the Kiskevély cave the artefacts selected as 'Jankovichian' tools were originally labelled as coming partly from the 'Magdalenian' (i.e. Gravettian or Epigravettian), partly from the Mousterian layer: DoBOSI-VÖRÖs 1994, 19, cf. GÁBORI-CsÁNK 1993,
139, pl. X,1-5, XI,1-5. - At the same time, a double scraper published by Gábori-Csánk among the artefacts from the Jankovich cave in fact belongs to the Kiskevély assemblage: GÁBORI-CsáNK 1993, Pl. IIIab.2, cf. MARKó 2013, 17.

${ }^{15}$ Kadić-KRetzoi 1926-1927; Kadić 1934，101-102 (under the name of Esterházy cave). - The pierced canine was compared to the pieces found in the Herman Ottó cave and, accordingly, the site was dated to the Aurignacian period.

${ }^{16}$ Kretzor 1954, 38.

${ }^{17}$ Kretzol 1954, 42-43.

${ }^{18}$ Vértes 1962, 280; Vértes 1964, 317; Vértes 1965, 113, 159, 291.

${ }^{19}$ GÁBORI-CSÁNK 1983, 277; 1984, 16-17. - In fact, referring to the oral information by M. Roska, Vértes originally compared the leaf shaped point to the Jankovich artefacts and together with the alleged bone artefacts from this site he identified the site as belonging to the Transdanubian Szeletian: VéRTES 1955a, 265, 277.

${ }^{20}$ GÁBori-CsÁNK 1993, 141, Pl. XIIa-b, 1,2, cf. VÉrTES 1965, 113, Pl. XI.1-2.

${ }^{21}$ MésZÁros-VÉrTes 1954, 12, Plate XII: 4a-b.

${ }^{22}$ GÁBORI 1976, 80; GÁBORI-CSÁNK 1983, 276-277;

GÁBORI-CSÁNK 1984, 16

${ }^{23}$ GÁBORI-CSÁNK 1993, 84, 142.

${ }^{24}$ GÁBORI-CSÁNK 1993, 83. 
Recently M. Patou-Mathis summarizing her observations on the osseous artefacts suggested that this locality has been repeatedly used from the Middle Palaeolithic until the recent Prehistoric times ${ }^{25}$ and pointed out that the artefacts were collected from three features probably representing different periods. However, the data given by Gy. Mészáros and L. Vértes clearly show that the leaf shaped scraper was found in layer 5 of feature 2, together with the radiolarite flakes and the double-bevelled point, ${ }^{26}$ as well as several bone implements made of elk ulna, ${ }^{27}$ pseudo-metapodial awls, ${ }^{28}$ and finally, the single tool made of ibex bone. ${ }^{29}$

The Lovas site was originally dated to the Würm I-II interstadial, later to the Early Würm (Varbó phase, following the mammal biostratigraphy developed in Hungary, MIS 5a) ${ }^{30}$ or to the Middle or Upper Würm (Istállóskö phase) ${ }^{31}$ In our view, the leaf shaped scraper was most probably found in a secondary position and does not belong to the otherwise homogenous Late Palaeolithic assemblage of the characteristic, specialised bone tools associated with reliable radiocarbon dates. ${ }^{32}$ Anyway, systematic taphonomic, typological and technological studies of this important assemblage will be necessary in the future.

Finally, from the Pálffy/Dzeravá skála cave (Western Carpathians, Slovakia) only the single bifacially worked piece excavated by J. Hillebrand was originally mentioned by V. Gábori-Csánk. ${ }^{33}$ Later the presence of the Levallois flaking, ${ }^{34}$ leaf shaped scrapers and pieces similar to the Faustkeilblatt-type were also identified on the drawings published by F. Prošek. At the same time, some artefacts were compared to the tools known from the Kiskevély ${ }^{35}$ and the Jankovich cave. Consequently, Gábori-Csánk classified each 'Szeletian' lithic from this cave as belonging to the Jankovichian industry. ${ }^{36}$ Recently, however, the presence of both the Szeletian or Jankovichian artefacts in the Dzeravá skála assemblage were questioned and the single bifacially worked tool found during the 2002-2003 excavations in the middle part of layer 11 was classified as belonging to the Micoquian industry after an infinite radiocarbon date from the same level. ${ }^{37}$

In the last ten years the problem of the Jankovich-type artefacts was discussed by Zs. Mester in connection with the so-called technological investigations of the bifacial tools from the Szeleta and the Jankovich caves. ${ }^{38}$ The result of the investigations suggested that the asymmetric forms, generally made on flakes, and considered as the characteristic forms of the lower layer of the Szeleta cave are identical with pieces of the Jankovich cave. Earlier ${ }^{39}$ we pointed out several problems concerning the low number of studied pieces in each assemblage, ${ }^{40}$ the pointless use of percentages when the studied population is well below 100 elements and the contradictions at the stratigraphic interpretation of certain layers, especially at layer 4 of the Szeleta cave. ${ }^{41}$

${ }^{25}$ Patou-Mathis 2002. - Earlier V. Gábori-Csánk raised the possibility of two independent periods of ochre exploitation at the same site, as a possible explanation for the occurrence of the decorated ulna implement and the antler point in the Lovas assemblage: GÁBORICsÁNK 1993, 49.

${ }^{26}$ Mészáros-Vértes 1954, 5, Fig. 11,2 - cf. PatouMATHIS 2002, 174

${ }^{27}$ Including the largest artefact, mentioned by PatouMathis as a completely polished tool and dated to the later Prehistory: MészÁros-Vértes 1954, 7, Pl. I,3 - cf. Patou-Mathis 2002, 167, 174, Fig. 7.

${ }^{28}$ Including pieces with both well preserved and heavily weathered surface: MÉSZÁros-VÉRTES 1954, 13, Plate IV, 1-4, 6-10, 12 - cf. PATOU-Mathis 2002, 174.

${ }^{29}$ MészÁros-Vértes 1954, 17, Plate IV,11. - cf. PATOUMATHIS 2002, 174

${ }^{30}$ DoBosi-Vörös 1979, 22. - In 1988 V. Gábori-Csánk placed the site into the last interglacial (Süttő faunal phase, MIS 5e) GÁBORI-CSÁNK 1990, 98-99.

${ }^{31}$ VÖRÖS 2000, 194, cat. nr. 101. - In the seventies D. Jánossy placed the Lovas site to the same period because of the presence of the Szeletian artefacts: JÁNOSSY 1977, 143. In fact, the Istállóskő phase was dated to the Middle Würm by D. Jánossy and to the Upper Würm by I. Vörös.

${ }^{32}$ Dobosi 2006; SAJó et al. 2015.

${ }^{33}$ GÁbORI-CsÁNK 1983, 278-279; GÁBORI-CsÁNK 1984, 17
${ }^{34}$ The use of this method was observed during the recent evaluation of the assemblage too: KAMINSKÁ et al. 2005, 41, 45, Fig. 25,5.

${ }^{35}$ The given tools from the Kiskevély cave were classified earlier as belonging to the Mousterian industry (see note 14) and they are very similar, however, to the Tata artefacts.

${ }^{36}$ GÁBORI-CSÁNK 1993, 80. - In the same volume the bifacially worked tool excavated by J. Hillebrand in the Pálffy cave/Dzeravá skála was listed among the tools from the Jankovich cave: GÁBORI-CsÁNK 1993, Pl. Ia-b. 3. - cf. MARKó 2013a, 17, note 29.

${ }^{37}$ KAMINSKÁ et al. 2005, 55; KAMINSKÁ 2014, 94-95.

${ }^{38}$ Mester 2010; Mester 2011; Mester 2014a.

${ }^{39}$ MARKó 2016.

${ }^{40}$ For instance, in a recent paper Zs. Mester claimed that seven of the 18 asymmetric pieces excavated in the Szeleta cave were found in the upper layers 5, 6 and 6a, nine artefacts in the lower layers 2, 3 and 4, and finally, no stratigraphic data are available in the case of further seven pieces. This way, however, the number of the asymmetric pieces is not 18 but 23. and in fact, he analysed 17 leaf shaped implements: Mester 2017, 78. - It is embarrassing, that in a paper published in the preceding year the number of the asymmetrical pieces was 13 , seven of them were from layers 5 and 6 and six pieces from layers 4 and 3: LeNGYEL et al. 2016, Table 5.

${ }^{41}$ Mester dated this assemblage to the early Szeletian. This is, however, inconsistent with the data presented in the same papers, as the majority of the leaf shaped artefacts from this stratigraphic unit belong to the group characteristic for the Evolved Szeletian: MESTER 2011, tabl. 4; MESTER 2014a, Tabl. 4. - c.f. MARKó 2016, note 1.

Acta Archaeologica Academiae Scientiarum Hungaricae 70, 2019 
In our view, the information available from the more than 100 years old excavations of the Szeleta is not sufficient to make well based conclusions in the 21 st century. ${ }^{42}$ Furthermore, our studies shed some light to the role and intensity of the post-depositional effects, which could change basically the stratigraphic position of the given artefacts. ${ }^{43}$ Similarly, the Late Gravettian classification of the assemblage from layer 3 and 4 was rejected on the strength of the presence of the asymmetric leaf shaped points and the occurrences of the Gravettian tools were interpreted as an admixture. ${ }^{44}$ At least in some cases, however, the error occurred after the excavations with the incorrect stratigraphic and typological determination of the artefacts. ${ }^{45}$

\section{THE STUDIED ASSEMBLAGES}

Ultimately, of the Transdanubian Seletian/Jankovichian sites very few or no stratigraphic information is available from the Jankovich, Kiskevély, Szelim and Csákvár caves, while the recent evaluation led to the conclusion that the open-air site of Lovas and the Pálffy/Dzeravá skála cave belong to different, Late Palaeolithic and Micoquian industry. These observations raised the question of the validity of the term 'Jankovichian'. In the present paper we analyse the available information from three localities excavated after World War II in the north-eastern part of the Transdanubia: the Pilisszántó rock shelter II, the Bivak and the Remete Felső caves (Fig. 1), that may serve further evidences to this problem.

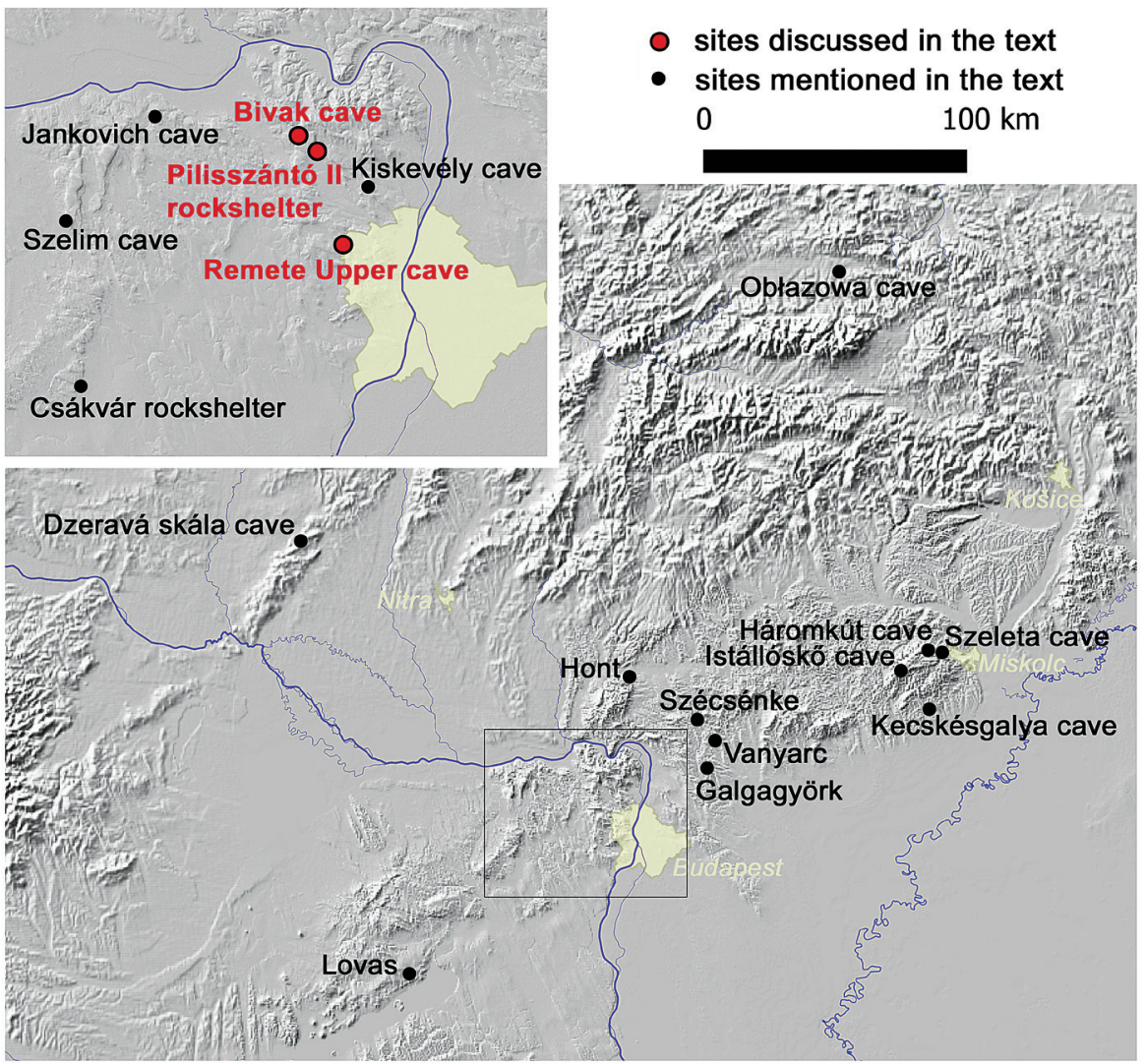

Fig. 1. The localities discussed and mentioned in this paper (map constructed by B. Holl)

${ }^{42}$ MARKó 2016, 8-10.

${ }^{43}$ MARKó 2016, 10-12.

${ }^{44}$ LENGYEL et al. 2016. - The 40-36 ka B.P. radiocarbon dates from these layers confirm that the assemblages are clearly older than the Late Gravettian: HAUCK et al. 2016, Table 4.
${ }^{45}$ E.g. in the case of the allegedly shouldered point from layer 4: LengYel et al. 2016, 177, Fig. 4,9. - cf. MARKó 2016, 24, Fig. 12,1, note 8 


\section{Pilisszántó Rock shelter II}

The site is lying in the southern part of the Pilis hill, close to the bottom of the valley, at $386 \mathrm{~m}$ a.s.l. The infilling of the little chamber was partly excavated in 1946 by L. Vértes. In the Pleistocene layers only two atypical chipped stone artefacts of greenish radiolarite (Fig. 2.1) and Slovakian obsidian (Fig. 2.2) were found. The pieces were first dated to the Magdalenian, ${ }^{46}$ later to the Transdanubian Szeletian ${ }^{47}$ and finally to the Jankovichian ${ }^{48}$ industry. Recently the occurrence of obsidian as an extralocal raw material in this assemblage led K. Biró to date the site to Early Upper Palaeolithic. ${ }^{49}$
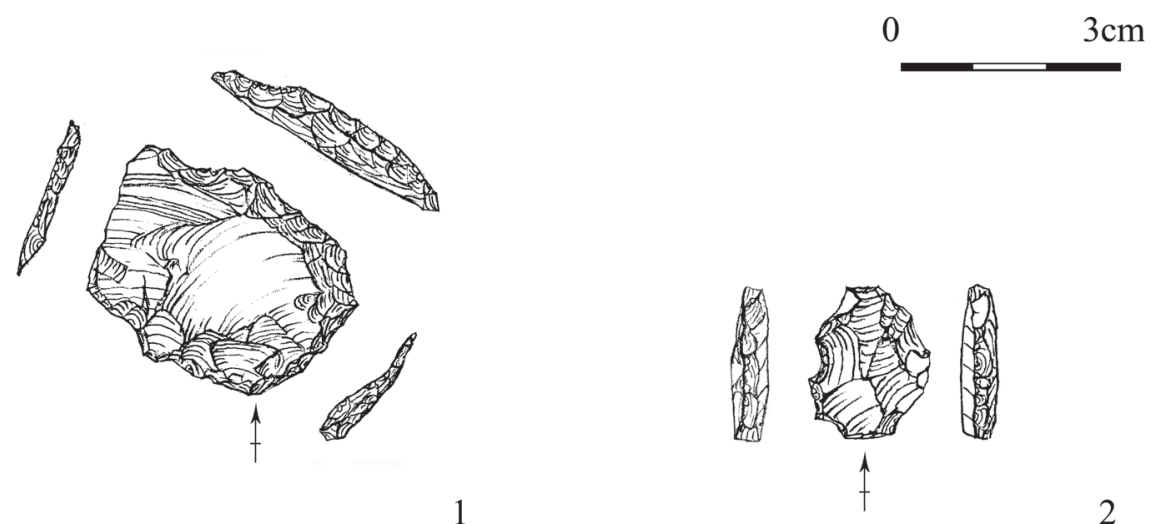

Fig. 2. Lithic artefacts from the Pilisszántó II rockshelter (drawing by K. Nagy)

The implements were classified as Szeleta scrapers, ${ }^{50}$ later scrapers with large bulb of percussion, similar to the Jankovich tools ${ }^{51}$ and, rather surprisingly, as a unifacial leaf shaped scraper and a scraper. ${ }^{52}$ In our view, both pieces belong to the group of the heavily fragmented blanks partly showing traces of intentional modification, but partly shaped by natural factors. These forms, sometimes called as 'raclettes', are known not only from the Jankovich cave but also from the Dzeravá skála ${ }^{53}$ and Szeleta ${ }^{54}$ caves as well as from the lower ('Aurignacian I') layer of the Istállóskő cave in the Bükk Mountains, ${ }^{55}$ clearly illustrating the problems with the typological classification of these partly naturally fragmented lithics.

During the excavations of the Pilisszántó rock shelter II several Pleistocene layers and traces of important erosional events were documented. According to the original report the artefacts were found in the lower layer group (layers 8-10). ${ }^{56}$ Later the lowermost, brownish-red layer $10^{57}$ or the lower brown layer $9^{58}$ was given as the place of recovery of the artefacts. The recent stratigraphic evaluation of the site placed the occurrence of the lithics to the border of the reddish brown and the red-brown loam. ${ }^{59}$

${ }^{46}$ VÉRTES 1951.

${ }^{47}$ VÉRTES 1955a; VÉRTES 1965.

${ }^{48}$ GÁBORI-CsÁNK 1983; GÁBORI-CsÁNK 1984; GÁBORICSÁNK 1993

${ }^{49}$ BIRÓ 1984.

${ }^{50}$ VÉRTES $1965,161,325$

${ }^{51}$ GÁbORI-CSÁNK 1983, 281; GÁBORI-CSÁNK 1984, 18.

${ }^{52}$ GÁBORI-CSÁNK 1993, 140-141. - Importantly, the artefact from the Jankovich cave, mentioned as similar to the piece made of obsidian (Fig. 2.2 in the present paper) is most probably the fragment of a typical blade, collected from the Gravettian layer: GÁBORICsánK 1993, IX,9, VIII,19; cf. MARKó 2013, Fig. 2, 3.

${ }^{53}$ The pieces excavated by F. Prošek were enumerated among the artefacts from the uppermost level of layer 11: KAMINSKÁ et al. 2005, 45-50, Fig. 28.

${ }^{54}$ MARKó 2016, 16, 19, Table 3.

${ }^{55}$ MARKÓ 2015, 22.
${ }^{56}$ Layer 8: ferruginous loam, layer 9: brown loam and layer 10: brownish red loam with limestone fragments: VÉRTES 1951, 228229, Fig. 1; VÉRTES 1955b, 395-398. - Using the original field documentation the stratigraphic sequence of this cave was revised in the 1980s: the former layer 8 was renamed to Layer 7 (light tan loess with yellow grains), layer 9 to Layer 8 (reddish brown clay) and the lowermost layer 10 to Layer 9 (red brown clay): DoBosı-VöRös 1986, 27.

${ }^{57}$ VÉRTES 1955a, 270 - According to the excavation diary, this stratigraphic unit (Layer 9, following the revised layer sequence) was completely sterile in archaeological and paleontological point of view, see: DoBOSI-VÖRÖs 1986, 27.

${ }^{58}$ VÉRTES 1965, 325. - Identical with Layer 8 by Dobosi and Vörös: DoBOSI-VÖRÖs 1986.

${ }^{59}$ Layers 9 and 10 by Vértes or Layers 8 and 7 of the revised sequence. Following the archaeological considerations, i.e. the presence of the Jankovichian industry it was suggested that the scrapers were found in the uppermost horizon of the reddish brown Layer 8: DoBOsI-Vörös 1986, 30, Fig. 1. 
The formation of the reddish brown layer was estimated to the Würm I or Pre-Würm, however, as in this layer only a single indifferent bone fragment was found this age was based exclusively on the presence of the Jankovichian implements. ${ }^{60}$ The macro mammal remains from the overlying reddish brown loessy loam ${ }^{61}$ suggested for an interstadial date, most probably the Szeleta faunal phase (Würm I/II, Hengelo interstadial, MIS 3), noting the striking similarities with the corrected fauna from the Lower layers of the Pilisszántó I rock shelter. ${ }^{62}$ Later the given layers from these localities were enumerated among the localities of the Istállóskő phase (Denekamp interstadial MIS 3). ${ }^{63}$

By and large, the stratigraphy of the Pilisszántó rock shelter II is rather problematic: the layer from which the lithics were reported has not been documented and between the two lowermost layers a stratigraphic hiatus is indicated. ${ }^{64}$ It seems to be evident, that the two artefacts are dated to a period not younger than the MIS 3 . In the assemblage of this rock shelter, however, no bifacial implements were found and in our view, the presence of not typical tools and fragments ('raclettes') does not justify the Jankovichian classification of the little lithic assemblage.

\section{Bivak cave}

This cave is lying at a distance of $3.5 \mathrm{~km}$ from the Pilisszántó rock shelters, in the northern part of the Pilis hill, opening at a large relative height into western direction. During the autumn of 1953 D. Jánossy and L. Vértes excavated the Pleistocene layer sequence of yellow or locally orange-coloured, yellowish grey, grey and brown loam underlying the Holocene humus layer. ${ }^{65}$ The field works yielded four lithics and two antler tools (Table 1). The bifacially worked leaf shaped tool made of patinated brown radiolarite (nr. 1 in Table 1, Fig. 3.1) and a unilaterally retouched blade were excavated (nr. 6 in Table 1, Fig. 3.4) at the border of the grey and the yellowish grey layer. However, the stratigraphic evaluation of the site, similarly to the Pilisszántó rock shelter II showed an important hiatus between these two layers. A 'raclette' of Szentgál-type (nr. 3 in Table 1, Fig. 3.3) and a retouched blade-like flake of greenish grey radiolarite (nr. 1 in Table 1, Fig. 3.2), both made on blanks removed from core edge, were documented in the grey layer, close to each other. Finally, one of the antler tool fragments was most probably found at the border of the orange-coloured and the greyish yellow layer (nr. 2 in Table 1), the other one in the disturbed part of the cave, where only the grey and the reddish brown layers were preserved. ${ }^{66}$

Table 1.

Artefacts recovered in the Bivak cave (see Fig. 3)

\begin{tabular}{|l|l|l|l|}
\hline nr. & classification & place of recovery & date of recovery \\
\hline 1 & leaf shaped scraper of radiolarite & at the border of the yellowish grey and grey layers & 24.09 .1953$. \\
\hline 2 & antler point fragment & orange-coloured and yellowish grey layer & 29.09 .1953$. \\
\hline 3 & antler point fragment & disturbed sediment & 1.10 .1953$. \\
\hline 4 & raclette of Szentgál type radiolarite & grey layer & \\
\hline 5 & raclette of greenish grey radiolarite & grey layer & \\
\hline 6 & blade fragment & at the border of the yellowish grey and grey layers & \\
\hline
\end{tabular}

Concerning the chronology of the grey layer and the lithics, V. Gábori-Csánk supposed that the associated fauna is typical to the Early Würm period. ${ }^{67}$ However, already in the seventies the palaeontologist D. Jánossy enumerated this site among the localities of the Istállóskő faunal phase ${ }^{68}$ noting that there are important differences in the faunal composition of the Bükk and the Pilis sites. Even if this opinion could have been influenced by the presence of the 'Szeletian' artefacts, Jánossy pointed out that the remains identified as Megaloceros belong in fact to

${ }^{60}$ Dobosi-Vörös 1986, 43. - Earlier D. Jánossy dated the reddish layers from the rock shelter to the Istállóskő faunal phase after the presence of Szeletian tools: JÁNOSSY 1977, 143.

${ }^{61}$ Light tan loess Layer 7 with the dominant species of cave bear remains and the presence of cave hyena, lynx, bison, arch, woolly rhino, horse, elk and chamois: DoBosı-VöRös 1986, 36-38.

${ }^{62}$ DobOSI-VÖRÖs 1986, 43.

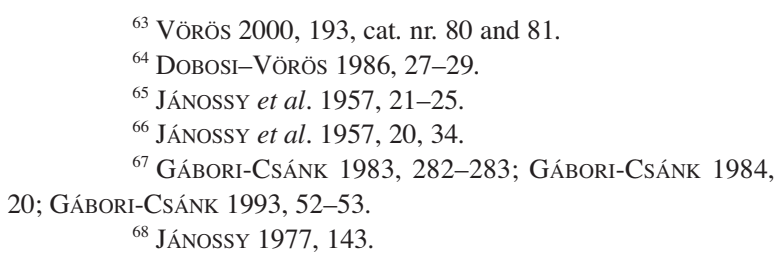

${ }^{63}$ VÖRÖs 2000, 193, cat. nr. 80 and 81.

OSI-VOROOS 1986, 27-29.

${ }^{66}$ JÁNOSSY et al. 1957, 20, 34

I-CSÁNK 1993, 52-53.

${ }^{68}$ JÁNOSSY 1977, 143 

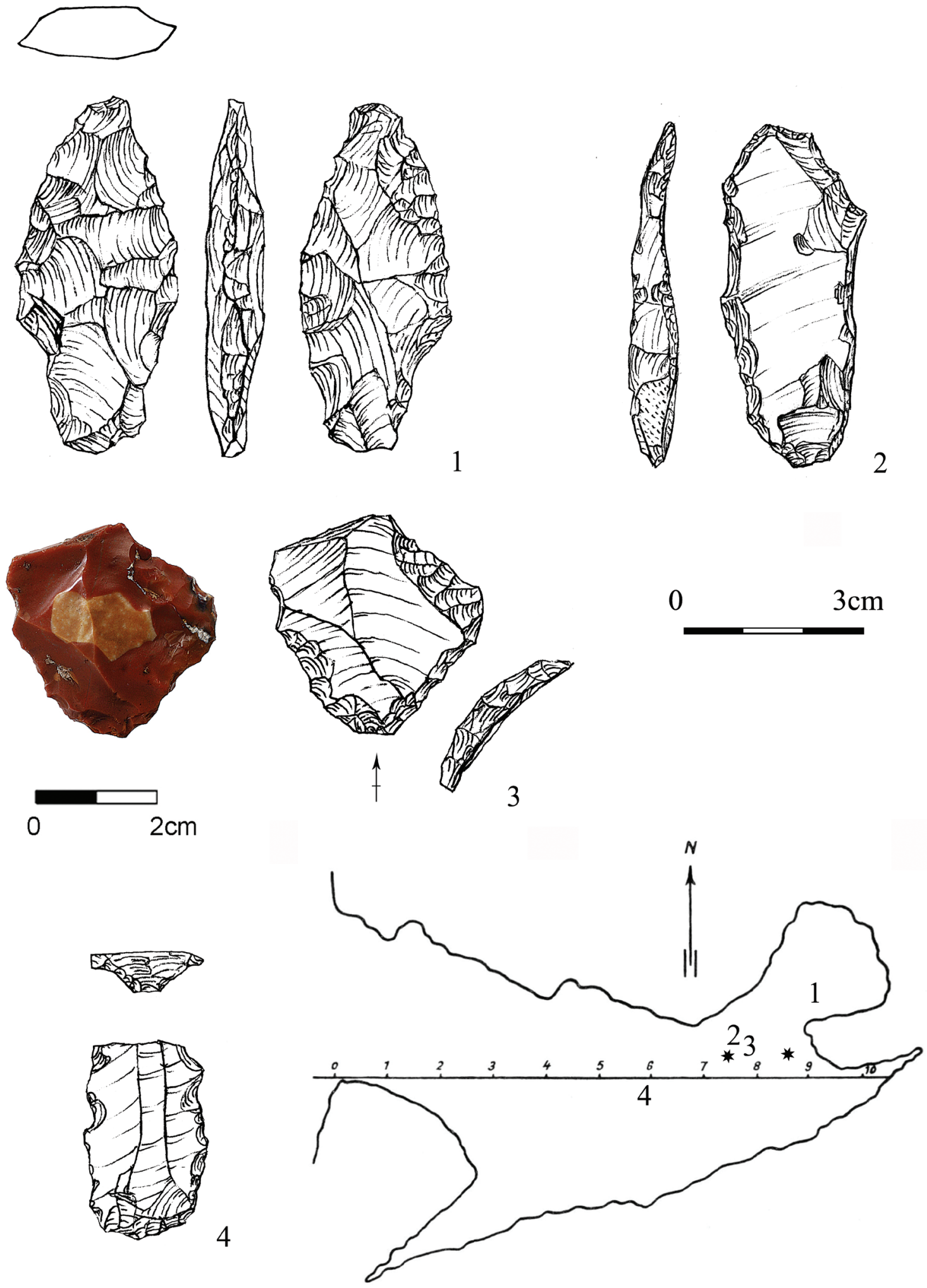

Fig. 3. Bivak cave: lithic artefacts (drawing by K. Nagy) and the distribution of the including the antler tools (displayed by stars) in the cave (following JÁNOSSY et al. 1957 modified)

Acta Archaeologica Academiae Scientiarum Hungaricae 70, 2019 


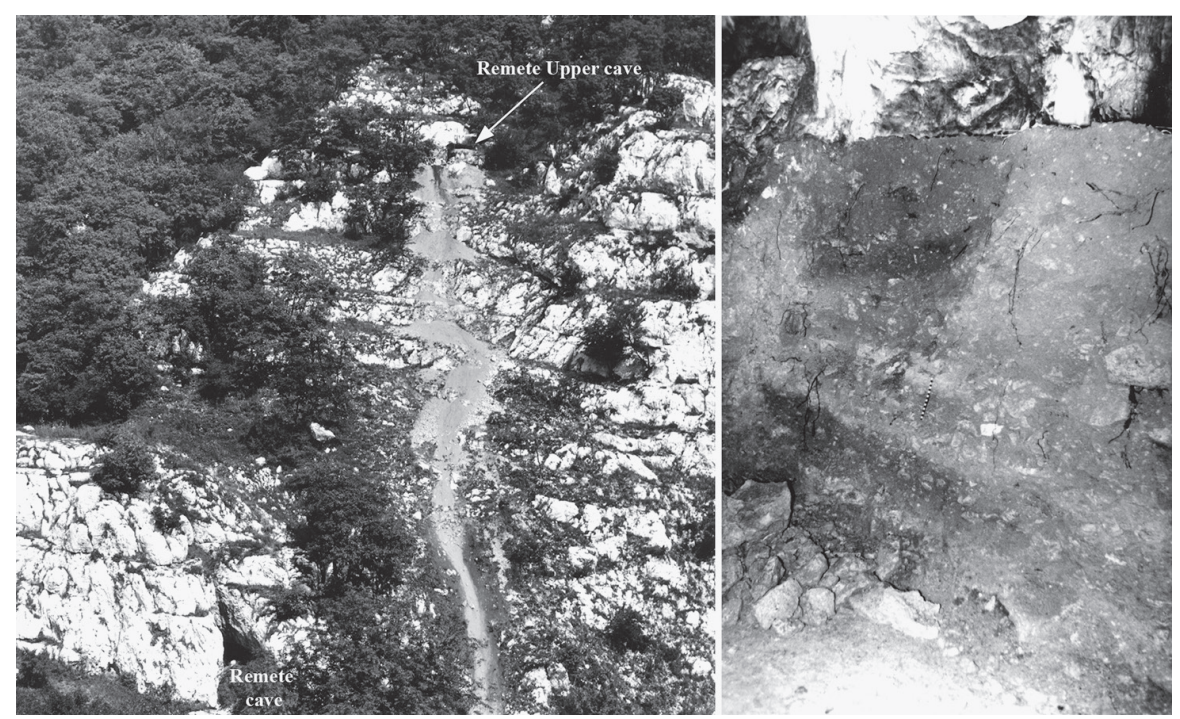

Fig. 4. Remete gorge: the entrances of the caves during the excavations and the longitudinal section in the inner chamber of the Remete Upper cave ${ }^{69}$

the taxon of Cervus elaphus, and acknowledged, that the giant deer finds younger than the Subalyuk phase (first Würmian Pleniglacial, MIS 4) should be revised. ${ }^{70}$

In total, during the relatively well documented excavations in the Bivak cave rather poor but characteristic lithic assemblage and most probably at least one of the osseous artefacts was found in the grey layer. The age of this stratigraphic unit is, however, not known precisely, most probably it can be dated to the Middle Würm period (mis 3). Finally, the most recent review of the Upper Pleistocene mammal faunas from Hungary ${ }^{71}$ did not mention this site.

\section{Remete Upper cave}

This little cave is opening in south-western direction, at the height of $70 \mathrm{~m}$ above the bottom of the narrow and deep Remete gorge (Fig. 4), in the north-western part of Budapest. The site was excavated by V. Gábori-Csánk in $1969-71 .^{72}$ According to the stratigraphic evaluation of the cave infilling by the geographer F. Schweitzer ${ }^{73}$ the $^{-1}$ large limestone fragments lying directly on the bedrock were dated to the glacial maximum of the penultimate glacial (MIS 6) and the imbedding reddish brown loam was formed during a later mild period (MIS 5e?). The lower part of the overlying layer 4 (reddish loam without limestone fragments) dated to the end of the last interglacial was formed on a discordant surface, showing a washout in the layer sequence. The upper level of the same layer with the lithic artefacts, as well as the remains of 24 vertebrate taxa and the human teeth is yellowish loessy sediment mixed by sharp limestone fragments, documenting the cooling period of the Early Würm (preceding MIS 4). The grey coloured layer 3 with sharp limestone fragments was interpreted as a cryoturbated sediment, ${ }^{74}$ overlain by the brown humic layer 2, missing from the inner chamber of the cave and by a recent rendzina soil layer 1 both dated to the Holocene.

The number of the lithics excavated in the upper level of layer 4 was $14^{75}$ or $12,{ }^{76}$ actually eleven pieces are catalogued in the collection of the Budapest History Museum. ${ }^{77}$ This way, the Remete Upper cave is the second richest locality of the Jankovichian industry in Hungary. Regrettably, in spite of the reports by the excavator ${ }^{78}$ the place of

${ }^{69}$ JÁNOSSY 1977, 144. - cf. DOBOSI-VÖRÖS 1986, 43. Recently the late survival of giant deer was evidenced from Central European localities too: LISTER-STUART 2019.

${ }^{70}$ VöRÖS 2000

${ }^{71}$ GÁbORI-CSÁNK 1970; GÁBORI-CSÁNK 1971; GáBoriné CsáNK 1973.

${ }^{72}$ GÁBORI-CSÁNK 1983, 258-263; GÁBORI-CSÁNK 1984, 8-10; GÁBORI-CSÁNK 1993, 58-60.

Acta Archaeologica Academiae Scientiarum Hungaricae 70, 2019
${ }^{73}$ However, in this layer fossil and subfossil bones and rather atypical Prehistoric sherds were also found, showing that the redeposition dates at least partly to the Holocene: GÁBORI-CsánK 1983, 253; GÁBORI-CSÁNK 1984, 6.

${ }^{74}$ GÁBORI 1981, 98.

${ }^{75}$ Including nine formal tools and three flakes: GÁBORICSÁNK 1983, 267; GÁBORI-CSÁNK 1984, 12; GÁBORI-CSÁNK 1993, 143. 
recovery of the lithic artefacts could be unambiguously identified only in four cases. The data enumerated in Table 2 are based on the laconic notes found in the field diary, ${ }^{79}$ summarising very shortly the observations of one or two days.

The first lithic, a proximal fragment of a blade-like flake of radiolarite with pebble cortex and very slight traces of secondary modifications (Fig. 5.3) was found in trench $3 .^{80} \mathrm{~A}$ half finished bifacial tool made on a flake of nummulithic chert ${ }^{81}$ with dihedral base and centripetal dorsal scars (nr. 9 in Table 2, Fig. 5.1) and a side scraper of Szentgál-type radiolarite with facetted base and unidirectional dorsal scars (nr. 8 in Table 2, Fig. 5.2) were excavated at the northern wall of the cave. ${ }^{82}$ These later tools were reported to be found close to the human remains. ${ }^{83}$

Finally, among the non-catalogued artefacts from the cave there is a box with the label ' $70.7 .21^{\text {' }}{ }^{84}$ and ' $3 / 1$ under the humus, in a yellowish lens'. We suspect that the atypical flake of radiolarite (probably the missing twelfth lithic artefact mentioned by the excavator, ${ }^{85}$ the piece of nr. 13 in Table 2) and the two cave bear teeth together with the Glycymeris obovata shell could have been excavated in 1970 in the inner chamber of the cave. ${ }^{86}$

The details of the recovery of three bifacial tools, which could have been easy to recognise on the field and a half made piece were not documented in the field diary. One of them, a proximal and medial fragment of a long leaf shaped tool of hornstone ${ }^{87}$ or poor quality limnic quartzite (Fig. 6.2) was claimed to be one of the typical forms

Table 2.

Artefacts from the Remete Upper cave as reflected in the field documentation.

Pieces which could have been securely identified in the collection are written with bold

\begin{tabular}{|l|l|l|l|l|l|}
\hline $\mathbf{n r}$ & classification & place of recovery & $\begin{array}{l}\text { stratigraphical posi- } \\
\text { tion }\end{array}$ & $\begin{array}{l}\text { depth of } \\
\text { recovery }\end{array}$ & date \\
\hline $\mathbf{1}$ & flake of radiolarite & trench 3 & layer 4 & $\mathbf{- 1 0 0 - 1 2 0 ~ c m ~}$ & $\mathbf{1 2 - 1 3 . 8 . 1 9 6 9 .}$ \\
\hline 2 & flake of obsidian & trench 4 & top horizont of layer 4 & above $-100 \mathrm{~cm}$ & $14-15.8 .1969$. \\
\hline 3 & flake of obsidian & trench 4 & top horizont of layer 4 & above $-100 \mathrm{~cm}$ & $14-15.8 .1969$. \\
\hline 4 & flake of hornstone & trench 5 & layer 4 & above $-120 \mathrm{~cm}$ & $21-22.8 .1969$. \\
\hline 5 & flake of hornstone & trench 5 & layer 4 & above $-120 \mathrm{~cm}$ & $21-22.8 .1969$. \\
\hline 6 & shed antler (red deer) & trench 6, at the wall of the cave & at the border of layer 3-4 & & 27.8 .1969$. \\
\hline 7 & flint tool encoche $)$ & trench 6, at the wall of the cave & layer 4 & & 27.8 .1969$. \\
\hline $\mathbf{8}$ & $\begin{array}{l}\text { notched tool made on a Levallois } \\
\text { flake }\end{array}$ & $\begin{array}{l}\text { at the border of trench 5-6a, } \\
\text { at the wall of the cave }\end{array}$ & layer 4 & & $\mathbf{2 - 3 . 9 . 1 9 6 9 .}$ \\
\hline $\mathbf{9}$ & half made bifacial tool & trench 5, at the wall of teh cave, \\
from the rocky infilling & & & $\mathbf{6 - 7 . 9 . 1 9 6 9 .}$ \\
\hline 10 & flake & trench 3/2 & thin Pleistocene layer & & \\
\hline 11 & flake & trench 3/2 & thin Pleistocene layer & & \\
\hline 12 & flake & trench 3/2 & thin Pleistocene layer & & \\
\hline $\mathbf{1 3}$ & flake of radiolarite & square 3/1 & layer 4 & & $\mathbf{1 9 7 0}$ \\
\hline 14 & fossil shell & square 3/3 at the wall & layer 4 & 1970 \\
\hline 15 & canine of bear & square 3/3 at the wall & layer 4 & & 1970 \\
\hline 16 & canine of bear & square 3/3 at the wall & layer 4 & & 1970 \\
\hline
\end{tabular}

${ }^{76}$ Under the inventory number of 71.1.1-11. We are grateful for the friendly help for the colleagues working in the Aquincum Museum, Budapest.

${ }^{77}$ GÁbori-Csánk 1983, 267; GÁBORI-CsÁNK 1984, 12; GÁBORI-CsÁNK 1993, 59.

${ }^{78}$ Found in the Archives of the Budapest History Museum under the number of H 1406-2004 and of the Hungarian National Museum: V.91.1970.

${ }^{79}$ The numbering of the trenches in the field documentation differs from the published data. According to the papers by Gábori-Csánk the first lithic was found in trench 2, the second in trench 3, etc.: GÁBORI-CSÁNK 1983, 267; GÁBORI-CsÁNK 1984, 12; GÁBORI-CsÁNK 1993, 59

${ }^{80}$ MARKó-KÁZMÉr 2004.

${ }^{81}$ This later piece was repeatedly claimed as especially typical for the Jankovichian industry: GÁBORI-CsÁNK 1983, 267, Fig. 16,6; GÁBORI-CsÁNK 1984, 12, Fig. 16.6.
82 GÁBORI-CSÁNK 1983, 267; GÁBORI-CSÁNK 1984, 12 . According to the label on the box containing the teeth, the two incisors were found in the sample collected in trench 6/a, while the canine in $6 / 2$, each at the depth of $120 \mathrm{~cm}$ below the original surface.

${ }^{83}$ This is certainly not the inventory number of the items, but probably the date of recovery (i.e. 21 July 1970).

${ }^{84}$ JÁNOSSY 1977, 144 DOBOSI-VÖRÖS 1986, 43; LISTERSTUART 2019, cf. note 76.

${ }^{85}$ GÁBori-CsÁNK 1983, 267, 269; GÁBORI-CsÁNK 1984, 12, 13; GÁBORI-CSÁNK 1993, 59.

${ }^{86}$ The term 'hornstone' is used in a conventional way, for the siliceous rocks formed in the shallow marine sediments during the Triassic Age. This relatively poor quality raw material was used during the Middle Palaeolithic (Érd), but typically during the Copper and the Bronze Age: DiENES 1968; BIRó 2002.

${ }^{87}$ GÁbori-CsánK 1983, 267, Fig. 16,3; GÁBori-CsÁnK 1984, 12, Fig. 16.3

Acta Archaeologica Academiae Scientiarum Hungaricae 70, 2019 

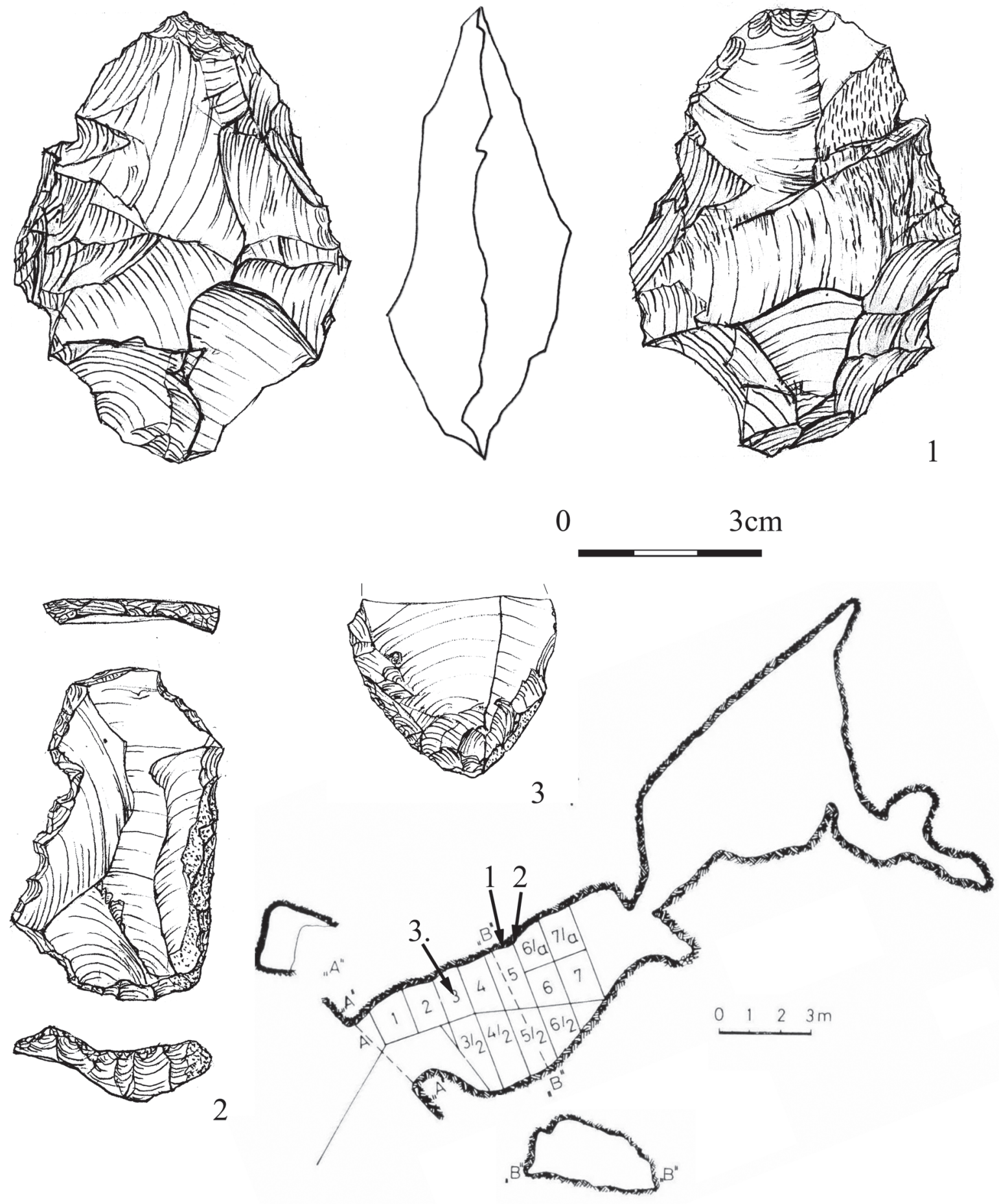

Fig. 5. Remete Upper cave: documented lithic artefacts (drawing by K. Nagy)

and the distribution of the pieces excavated in the cave in 1969 (following GÁBORI-CsáNK 1983 modified) 

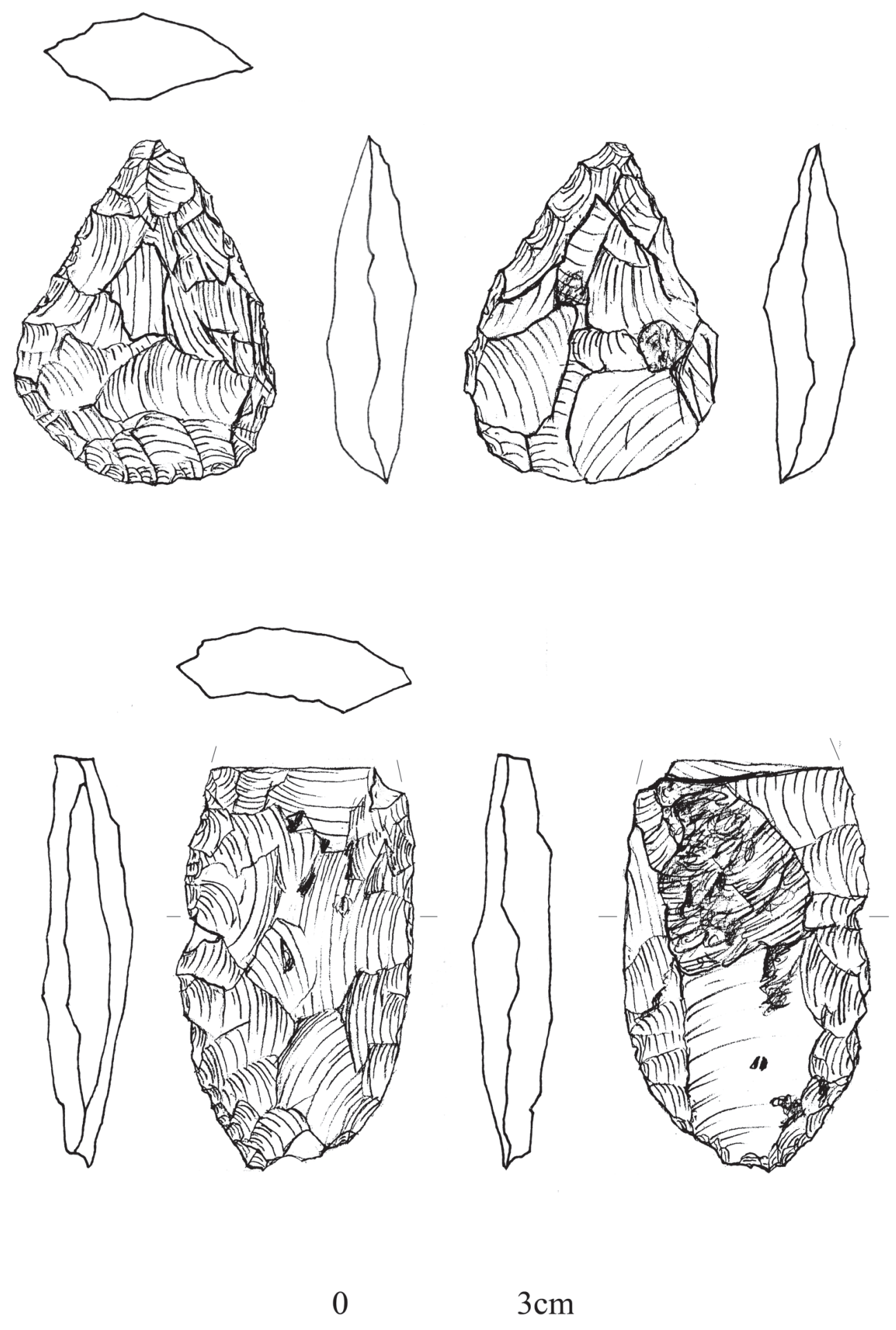

Fig. 6. Remete Upper cave: leaf shaped implements from unknown parts of the cave (drawing by K. Nagy) 
of the industry. ${ }^{88}$ Another piece, a plano-convex leaf shaped tool made on a flat cortical flake with a thinned bulb of percussion (Fig. 7.1) is comparable to the pieces known from Hont lying in the Ipoly valley in northern Hungary. ${ }^{89}$ The third piece, a plano-convex leaf shaped tool made of poor quality limnic quartzite is similar in outline to the Moravany-type points, and to a unifacially manufactured piece from the same site..$^{90}$ The tool from the Remete Upper cave was thinned on the ventral face by some flat removals with the exception of the tip, where it was intensively retouched (Fig. 6.1). Finally a piece made of low quality nummulithic chert pebble is interpreted as a half made bifacial tool, probably of a leaf shaped scraper, abandoned by the angular breakage pattern and the hinge removals (Fig. 7.2).

One of the unifacially worked artefacts found at an unknown place in the cave is a notched tool made on a debordant flake (Fig. 7.4). Its raw material, the brown hydrothermal rock is similar to the pieces known from the Börzsöny Mountains. ${ }^{91}$ Finally, the plunging flake of dull grey-coloured siliceous pebble with a retouched edge was probably fragmented during the excavations (Fig. 7.3).

Among the artefacts there is an amorphous piece with several scars, made of glass, most probably of artificial origin. This piece is possibly identical with the 'amorphous volcanic rock' mentioned in the papers ${ }^{92}$ or the notched tool of greenish Triassic flint of number 7 of Table 2.

It is interesting to note the presence of the obsidian artefacts (number 2 and 3 in Table 2, found in the topmost horizon of layer 4 in trench 4), which are not mentioned in the publications and cannot be identified in the Palaeolithic collection. In a box containing the Prehistoric artefacts from the cave, however, there is a blade fragment of Slovakian obsidian and another one of black coloured siliceous rock (which is, however, not obsidian), ${ }^{93}$ dated probably to the Copper Age (Ludanice culture), represented among the finds from this site. ${ }^{94}$

During the excavations the pit with the Bronze Age depot find was meticulously documented, ${ }^{95}$ but no other post-Palaeolithic features were described or depicted in the documentation. On the photograph from the inner chamber of the cave, however, a section of a pit is clearly visible (Fig. 4), ${ }^{96}$ suggesting that some lithics including the obsidian artefacts or the mentioned amorphous piece could have been intrusive finds in the Pleistocene layers.

Unfortunately, the mammal remains from the site have not been systematically analysed yet and only preliminary data are available from layer 4 of the first chamber (data by the palaentologist M. Kretzoi) ${ }^{97}$ According to the excavator, both the composition of the fauna (including remains of Lagopus, Ursus spealaeus, Crocotta, Equus, Leo, Coelodonta and Megaloceros) found in the upper level of layer 4 and the presence of the muskox Ovibos, is typical for to the period preceding the first Würmian Pleniglacial (Early Würm or 'Altwürm' period, MIS $5 \mathrm{~d}-\mathrm{a}){ }^{98}$ Recently, however, I. Vörös revised the Ovibos bones and concluded that the remains from the Remete Upper cave belong to a little bison ${ }^{99}$ and placed the age of yellow layer 4 into the Szeleta faunal phase, i.e. to the Hengelo interstadial. ${ }^{100}$ Taking into consideration the last appearance date of the giant deer in the Carpathian Basin, which is the discriminating species of the Szeleta and Istállóskö phases or the Hengelo and Denekamp interstadials ${ }^{101}$ the age of the fauna associated with the lithic tools cannot be securely placed to the first part of the last glaciation. ${ }^{102}$

${ }^{88}$ E.g. GÁbori 1964, 72, Pl. XIX.1; ZANDler 2010, Fig. 9.1.

${ }^{89}$ ZANDLER 2010, Fig. 9.2. - In the Moravány assemblage excavated by J. Bárta there are similar pieces without flat ventral retouch, too: NEMERGUT 2010, 192.

${ }^{90}$ The same raw material is also known from the Hont assemblage. Moreover, on the piece of the Remete Upper cave a number „124" written by ink is clearly visible. A similar label is found on the artefacts from Hont again.

${ }^{91}$ GÁBORI-CsÁNK 1984, 12. - In other papers this piece is referred as amorphous block of volcanic rock and it was suspected that the source region was not in the Tokaj Mountains: GÁBORI-CsÁNK 1983, 267; GÁBORI-CSÁNK 1993, 143.

${ }^{92}$ Stored under the inventory number 73.3.4-5 in the Prehistoric Collection of the Aquincum Museum.

${ }^{93}$ M. VIRÁG 1995.

${ }^{94}$ GÁbORI-CSÁNK 1983, 255, Fig. 4,13; GábORI-CsáNK 1984, 7-8, Fig. Fig. 8; GÁBORI-CsánK 1993, Fig. 15.

Acta Archaeologica Academiae Scientiarum Hungaricae 70, 2019
${ }^{95} \mathrm{Cf}$. the published drawing from the same part of the cave: GÁBORI-CsánK 1983, Fig. 15; GÁBORI-CsáNK 1984, Fig. 15; GÁBORI-CsánK 1993, Fig. 16.

${ }^{96}$ GÁBORI-CSÁNK 1983, 263-266; GÁBORI-CSÁNK 1984, 10-12; GÁBORI-CsáNK 1993, 61.

${ }^{97}$ GÁBORI-CSÁNK 1983, 263-265; GÁBORI-CSÁNK 1984, 10-11; GÁBORI-CSÁNK 1993, 61-63.

${ }^{98}$ VÖRÖS 2010, 43.

${ }^{99}$ VöRÖs 2000, 190, cat. nr. 31.

${ }^{100}$ Importantly, in the seventies M. Gábori reported the presence of Cervus elaphus and not Megaloceros from the cave: GÁBORI 1976, 79 - JÁNOSSY 1977, 144 Dobosi-VöRÖs 1986, 43; Lister-STUART 2019, cf. note 70.

${ }^{101}$ Mester 2011, 30; Mester 2014a, 53 - cf. Markó 2013, note 6.

${ }^{102}$ GÁBORI-CsánK 1983, 262-263; GÁBORI-CSÁNK 1984,

$7,10$. 

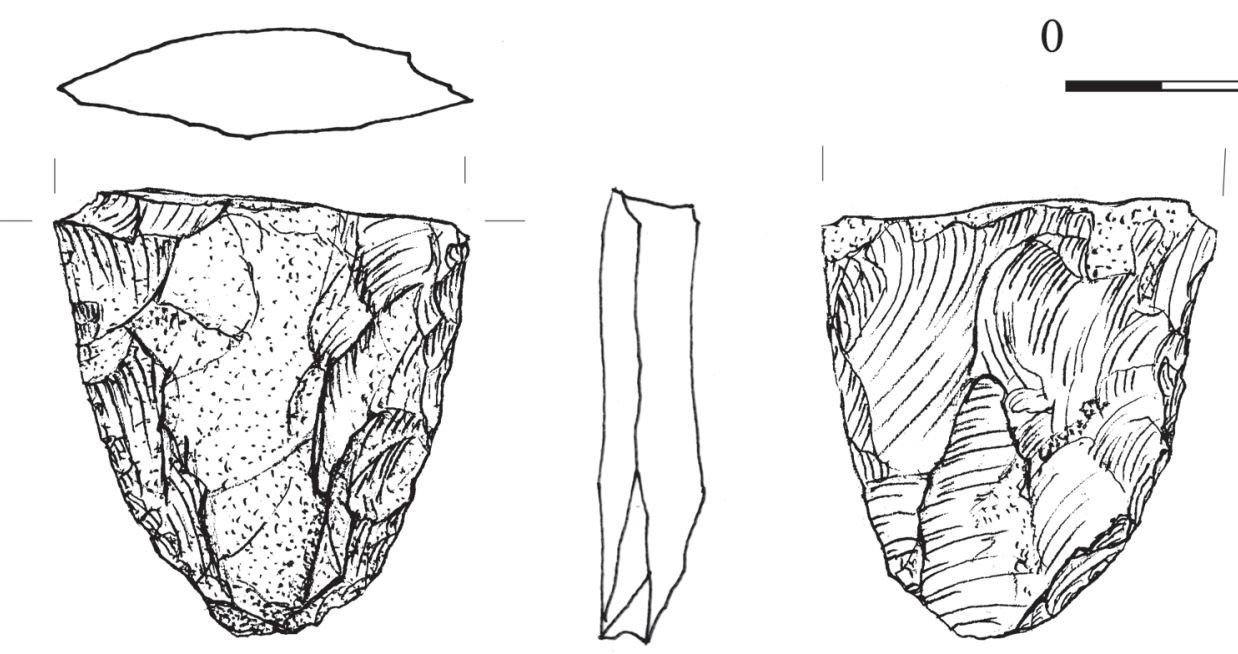

$3 \mathrm{~cm}$
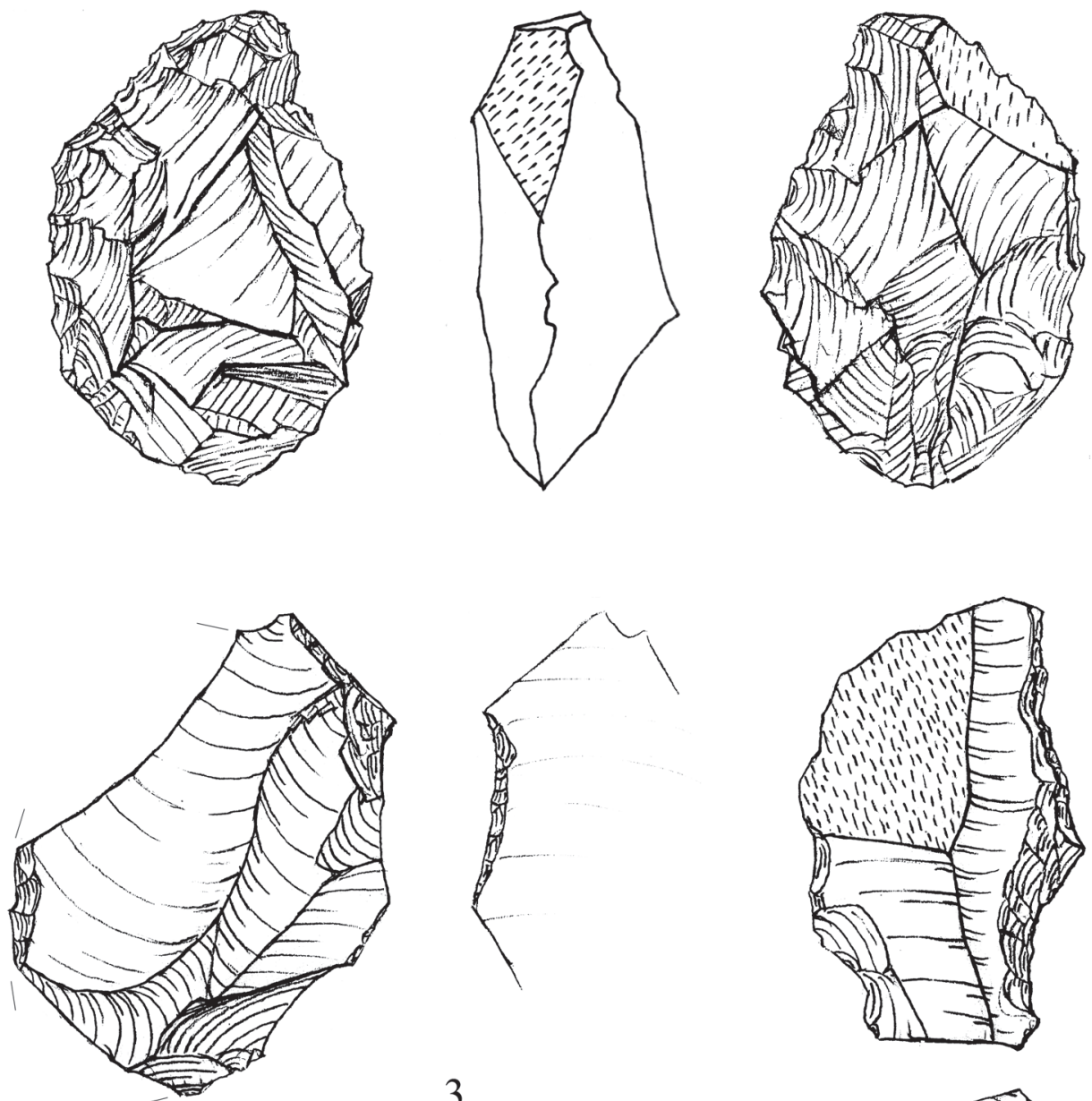

3

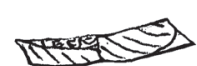

Fig. 7. Remete Upper cave: leaf shaped implement, half made tool and retouched pieces from unknown parts of the cave (drawing by K. Nagy) 
Table 3.

Charcoal remains from the 1969 excavaions of the Remete Upper layer

\begin{tabular}{|c|c|c|c|c|c|c|c|c|c|c|c|c|}
\hline $\begin{array}{l}\text { archaeological } \\
\text { label }^{103}\end{array}$ & $\begin{array}{l}\text { Quercus } \\
\text { cf. robur }\end{array}$ & $\begin{array}{l}\text { Quercus } \\
\text { cf. } \\
\text { sessilis }\end{array}$ & Quercus & $\begin{array}{l}\text { Fraxinus } \\
\text { cf. excel- } \\
\text { sior }\end{array}$ & Cornus & $\begin{array}{l}\text { Acer cf. } \\
\text { pseudo- } \\
\text { platanus }\end{array}$ & $\begin{array}{l}\text { Prunus } \\
\text { cf. spi- } \\
\text { nosa }\end{array}$ & $\begin{array}{l}\text { deciduous } \\
\text { tree }\end{array}$ & $\begin{array}{l}\text { Larix- } \\
\text { Picea }\end{array}$ & $\begin{array}{l}\text { Pinus cf. } \\
\text { sylvestris }\end{array}$ & pine & Total \\
\hline $4-100$ & 2 & & 1 & & & & 5 & 1 & & & 1 & 10 \\
\hline $5-80$ & 5 & & & & & 3 & & & & & & 8 \\
\hline $5 / 2-80$ & 5 & 1 & 3 & 1 & & & & & & & & 10 \\
\hline $\begin{array}{l}5-120 \text { (yellow } \\
\text { layer) }\end{array}$ & 1 & & & & 2 & 1 & & & 7 & 1 & 1 & 13 \\
\hline $6-120$ & 3 & & & & & & & & & & & 3 \\
\hline $\begin{array}{l}7 \text { debris in the } \\
\text { shaft }\end{array}$ & 6 & & & & 1 & 3 & & & & & & 10 \\
\hline $\begin{array}{l}\text { yellow layer } \\
\text { with large stone } \\
\text { fragments - } 130\end{array}$ & & & & & & & & & 5 & & & 5 \\
\hline total & 22 & 1 & 4 & 1 & 3 & 7 & 5 & 1 & 12 & 1 & 2 & 59 \\
\hline
\end{tabular}

Charcoals remains, exclusively belonging to larch or spruce (Larix-Picea group) were reported from layer 4 in the entrance of the cave, which seemingly confirmed the age of the layer and the human occupation predating the first Pleniglacial. ${ }^{104}$ However, pieces of charcoal were also found in the inner chamber in $1970^{105}$ and according to the field diary further fragments were observed e.g. in layer 4 of trench 3, where the first artefact $(\text { Fig. } 4.3)^{106}$ was found. Moreover, the report on the analysis of the charcoal pieces written in the Department of Applied Botany and Tissue Evolution of the Eötvös University, Budapest, and completed 5 December $1969^{107}$ clearly shows that in the samples a number of species, basically of deciduous trees were recognised (Table 3). In fact, larch or spruce was identified only among the charcoal pieces collected from the sediment of the penultimate glaciation and in another one associated with two hornstone flakes (nr. 4-5 in Table 2). However, in this latter layer remains of maple, dogwood and common oak were also found. Otherwise, the deciduous trees were common in the other samples, which, together with the presence of the intrusive artefacts may raise the question of later mixing of pieces in the cave sediment. ${ }^{108}$

After this short review it is clear that the age of the Palaeolithic assemblage from the Remete Upper cave is a very problematic question: the faunistic material has not been analysed in details and the palaeo-botanical data collected during the first excavation in 1969 and never published before reflects an unexpectedly complex picture. Several observations and indirect data suggest for the disturbance of the sediment, which were, however, not sufficiently documented. Bearing in our mind the low number of the lithic artefacts as well as the questions and doubts concerning their provenance, we conclude that this locality in itself is not adequate to define a distinct archaeological industry.

\section{THE ASSEMBLAGE FROM THE BIVAK AND REMETE UPPER CAVE: JANKOVICHIAN, SZELETIAN OR A LEAF SHAPED INDUSTRY?}

The recent review articles on the 'Szeletian'" 109 reflect a certain dichotomy from Hungary, based on the assemblages from two old excavated sites, the Szeleta and Jankovich cave. However, in 2003-2005 and 20071950 lithic artefacts including 32 typical tools and 10 retonched fragments of a Middle Palaeolithic industry with leaf shaped implements were excavated in a not disturbed artefact-bearing layer near Vanyarc, in the Cserhát Mountains.

${ }^{103}$ Interpreted as 4, 5, 5/2, 6 and 7 indicate the number of the trenches, $-80,-100,-120$ and -130 the depth in $\mathrm{cm}$ measured from the original surface.

${ }^{104}$ GÁBori-CsÁNK 1983, 276; GÁBORI-CsÁNK 1984, 12. According to the information published in the monograph, the pieces collected in the little chamber were classified as belonging to the Larix-Picea group: GÁBORI-CSÁNK 1993, 61.

$$
{ }^{105} \text { See: note } 80 .
$$

${ }^{106}$ In the Archives of the Budapest History Museum under the number of $\mathrm{H}$ 1405-2004.

${ }^{107}$ E.g. the pieces of charcoal collected from trench 4, approximately from the same level as the obsidian artefacts, suggest for an environment very similar to present day vegetation around the cave.

${ }^{108}$ Mester 2014b; Mester 2018.

${ }^{109}$ MARKó 2007; MARKó 2011a; MARKó 2012. - This way, the statement that '[beside the Szeleta and the Jankovich caves]... no more sites with rich collections in a stratigraphic position have been 
The evaluation of the assemblage ${ }^{110}$ led to the description of the 'Vanyarc type industry' defined after the typological evaluation of the lithic tools as well as the observation on the use of the raw material types, with the emphasis on the extralocal rocks. Moreover, in the last years rich and well preserved assemblages were also excavated in the same region, at Szécsénke and Galgagyörk. ${ }^{111}$ In our view, it is important to develop hypothesis and research questions from the well documented assemblages, ${ }^{112}$ which make possible to raise an issue of the variability of the leaf point industries in Northern Hungary. From this aspect the 'Jankovichian' and 'Szeletian' are less well defined variants of the Middle or Upper Palaeolithic entities with single poorly documented sites.

Both the Szeletian and the Jankovichian industries have been defined on typological ground, i.e. after the presence of leaf shaped implements. As these artefacts are missing from the Pilisszántó rock shelter II, this site cannot belong to these entities. ${ }^{113}$ At the same time, the interpretation of the recently excavated assemblages from the Dzeravá skála cave pointed to an interesting problem. In the uppermost level of layer 11 a 'raclette' and a small flake from bifacial retouch, ${ }^{114}$ in the overlying layer 9 among others a flake from the flat retouching was found. ${ }^{115}$ The presence of the waste material from the manufacture of bifacial tools raises the question on the '[post]Leafpoint' and 'Aurignacian' classification of the little assemblages, especially, that the associated $37 \mathrm{ka} \mathrm{B}$. P. radiocarbon ages are very similar to the dates published from the Szeletian sites in Moravia.

The Bivak and the Remete Upper caves are lying at a large relative height above the bottom of the valley and most probably served for very short occupations ('bivouac site'), ${ }^{116}$ similarly to the Istállóskő cave. Accordingly, the number of the excavated artefacts is low and their typological composition is rather one-sided: apart from the bifacial implements the formal tools are represented by side scrapers, and 'Szeleta scrapers' or 'raclettes', i.e. partly naturally modified pieces, partly reshaped blanks. The Middle Palaeolithic character of the assemblages is also reflected in the flakes with facetted base; however, in the absence of cores the technological evaluation is rather problematic.

Compared these assemblage to that one known from the Jankovich cave, the differences are found in the quantity and not the composition of the tools, suggesting that on this later site a palimpsest of very short occupations could have been excavated. However, the field works at this locality were not documented sufficiently.

It is important to stress the role of the extralocal rocks and pebble raw material used by the humans. In the Bivak cave, the three tools of radiolarite were made on three different macroscopic variants (including the Szentgál type $^{117}$ ), one of them certainly of alluvial origin. In the Remete Upper assemblage, beside the artefacts of nummulithic chert ${ }^{118}$ (Fig. 5.1; Fig. 7.2), the tool of grey silex (Fig. 7.4) and at least one of the radiolarite artefacts (Fig. 5.3) ${ }^{119}$ were certainly made on pebble raw material. In this later case, the source area of the pebbles is most probably found in the south-western part of Budapest, lying at a distance of $15 \mathrm{~km}$ from the site, where large outcrops of the Lower Miocene Budafok formation were found. From the same region sand layers with abundant Glycymeris remains, dated to the Oligocene were also reported, ${ }^{120}$ suggesting that the fossil shell could have been transported to the site together with the lithic raw material types.

uncovered so far. Our understanding of the Szeletian in Hungary is still based on the archaeological sequences from the two caves' is not correct: Mester 2018, 34; cf. Mester 2014b, 160.

${ }^{110}$ Excavations by K. Zandler and A. Markó. The field reports from these sites are under preparation.

${ }^{111}$ The average find density of the artefact bearing layer at Vanyarc was 37.5 pieces per square meters, while the maximum number of the pieces excavated in the Szeleta cave on 4 square meters in artificial levels of half meter in thickness was 29: MARKó 2012, 214 215; MARKó 2016, 24-27. - Although Zs. Mester thinks that it is meaningless to use the find density data for the Szeleta assemblages, these values reflect both the low number of the excavated artefacts and the factually low resolution of the documentation from the Szeleta, compared to th recent excavations: MESTER 2018, 35.

${ }^{112}$ For the same reason the assemblages from the Kecskésgalya cave in the southern part of the Bükk Mountains and the AH2 at the Willendorf II site do not belong to the Jankovichian and Szeletian, see: Mester 2000; Nigst 2012.

${ }^{113}$ KAMINSKÁ et al. 2005, 38, Fig. 18,1.

${ }^{114}$ KAMINSKÁ et al. 2005, 34-35, Fig. 17,1,3.
${ }^{115}$ Davies-Hedges 2005, 60, Fig. 1, Table 1.

${ }^{116}$ GÁBORI-CSÁNK 1983, 265; GÁBORI-CSÁNK 1984, 11.

${ }^{117}$ This term has been used since 1984 for a characteristic macroscopic variant, named after its most important outcrop. However, beside Szentgál a number of occurrences of this type were reported from the Bakony mountains (Lókút, Hárskút and Bakonycsernye) and even from Gerecse (Pisznice), lying at a distance of $20-25 \mathrm{~km}$ from the Bivak cave and $35-40 \mathrm{~km}$ from the Remete Upper cave: Bíró 1984, 49.

${ }^{118}$ At this raw material, the raw material of the artefacts without cortical surface are identified collected from secondary sources, as the primary outcrops of this special siliceous rock are not known. The occurrencces of nummulithic chert pebbles were reported from several pebble bearing formations dated from the Oligocene/ Miocene to the Holocene: MARKó-KÁZMÉR 2004.

${ }^{119}$ Earlier Gábori-Csánk has taken into consideration the primary radiolarite outcrops around Dorog: GÁBORI-CsÁNK 1983, 269; GÁBORI-CsÁNK 1984, 13.

${ }^{120}$ FÖLDVÁRY 1929, 38-40.

Acta Archaeologica Academiae Scientiarum Hungaricae 70, 2019 
Earlier we compared the Remete Upper cave assemblage to the uppermost artefacts from the Jankovich cave and to the Szeletian industry, after the presence of the pieces similar to the Moravány types. ${ }^{121}$

In a recent paper, however, we argued, that the name of this cultural entity is inappropriate, as it was not possible to define a well-defined assemblage from the eponymous site as the typical Szeletian material. Moreover, because of the problems with the excavations and the documentation of the Szeleta cave, as well as the questions concerning the site formation, we suggested to use 'Szeletian' exclusively for the localities of the Bükk Mountains. ${ }^{122}$

Concerning the Jankovichian, one of the few characteristic pieces of the Jankovich cave are the Levallois flakes and points thinned on their ventral face. ${ }^{123}$ Recently Zs. Mester, disputing this observation drew attention to the presence of a similar tool in the Háromkút cave (Fig. 8.1) in the Bükk Mountains. ${ }^{124}$ Though not mentioned, Mester seemingly follows the view by J. Hillebrand by enumerating the Háromkút tool among the 'Protosolutréan' finds. ${ }^{125}$ However, as similar pieces are not found in the in the Szeleta cave, the tool of the Háromkút cave is generally compared to the artefacts of the Transdanubian Szeletian or the Jankovichian and the Middle Palaeolithic 'rolled' industry of the Gudenus cave in Lower Austria. ${ }^{126}$

M. Gábori was the first to mention from the same site a 'D shaped scraper' 127 or raclette made of Korláttype material, also used in the Szeleta and Istállóskő cave (Fig. 8.2). Finally, according to the inventory book a less typical tool with alternating manufacture made on a tabular piece of metarhyolite/felsitic porphyry (Fig. 8.3) belongs to the same assemblage. ${ }^{128}$ These later artefacts were suspected to be collected by Hillebrand in $1923,{ }^{129}$ however, according to the excavator, during this season no archaeological artefacts were found. ${ }^{130}$ Apart from the uncertainty concerning the circumstances of the recovery of these artefacts, none of them can be regarded as a particularly typical form for the Early Szeletian of the Szeleta cave ${ }^{131}$ and this way, the assemblage of the Háromkút cave does not belong to this entity.

On the other hand, the Levallois blanks with ventral thinning at the tip of the tools were recently interpreted as half made tools. ${ }^{132}$ The scars on the artefact of nummulithic chert from the Remete Upper cave (Fig. 4.1), ${ }^{133}$ however, shows an entirely different manufacturing strategy, starting with broad removals from the whole perimeter of the ventral side of the flake. Furthermore, ventral thinning at the tip of another bifacial tool from the same site, similar in its outline to the Moravány types ${ }^{134}$ (Fig. 5.1) was clearly posterior to the large flat removals covering the entire ventral face.

In any cases, Levallois points and flakes with flat fine ventral thinning at the tip of the tools at their distal part, similar to the Jankovich and Háromkút items are missing from the studied assemblages. This way, the Jankovichian classification of Bivak and the Remete Felső caves is rather problematic.

In this paper several pieces were mentioned from the Remete Upper cave showing apparent typological similarities with the tools from Hont-Csitár or which were made on the raw materials known from the northern part of the Börzsöny Mountains. In 1964 the open-air site of Hont was discussed among the Mesolithic localities. ${ }^{135}$ Five years later M. Gábori performed excavations on the site, but regrettably, no documentation is accessible from the fieldworks ${ }^{136}$ and in 1976 an industry with both Middle and Upper Palaeolithic elements was shortly mentioned from Hont ${ }^{137}$ the Upper Palaeolithic and later artefacts were handed to the Palaeolithic collection of the Hungarian Na-

${ }^{121}$ MARKó 2013a, 20.

${ }^{122}$ MARKÓ 2016, 32.

${ }^{123}$ MARKÓ 2013a, 21.

${ }^{124}$ Mester 2017, 86-87.

${ }^{125}$ Hillebrand 1935, 19-20.

${ }^{126}$ KADIĆ 1934, 66-67; VÉRTES 1965, 142; GÁBORI 1976, 80; GÁBORI-CSÁNK 1983, 284-285; GÁBORI-CSÁNK 1984, 20-21; GÁBORI-CSÁNK 1993, 113; MARKó 2013a, 21.

${ }^{127}$ GÁbOri 1953, 29, Tabl. V,10.

${ }^{128}$ VÉRTES 1965, 103-104, 142.

${ }^{129}$ REGŐS-RINGER 2003.

${ }^{130}$ 'Dr Kadič gelang es nach zweiwöchenlicher Arbeit ein einziges Steinwerkzeug und dem Verfasser in ebenso langer Zeit nicht einmal ein Exemplar zu finden': HILLEBRAND 1935, 19.

${ }^{131}$ Gábori compared the scraper to the Mousterian forms, Vértes to the pieces known from the Jankovich cave: GÁBORI 1953, 29; VÉRTES 1965, 103-104.
${ }^{132}$ Mester 2018, 87.

${ }^{133}$ There is a special problem concerning the artefacts from the Remete Upper cave, classified as half-made tools of extralocal nummulithic chert. Namely, the lack of flakes and chips suggests, that the first steps of the manufacture were made out of the cave and they were transported to the site, where no further tool making was practiced. Otherwise, the angular breaking pattern on one of the pieces (Fig. 6.2) does not permit further tool making.

${ }^{134}$ In the Moravany assemblage the points with partial ventral retouch at the tip of the tool are well represented: NEMERGUT 2010, 192, Tab V,9,11.

${ }^{135}$ GÁBORI 1964, 70-72.

136 These excavations are not mentioned even among the yearly short reports on the archaeological research, listed in the volume 97 of the periodical Archaeologiai Értesítő. See: GÁBORI 1981, 100 , note 13 .

${ }^{137}$ GÁBORI 1976, 80-81. - cf. GÁBORI 1964, 70-72. 

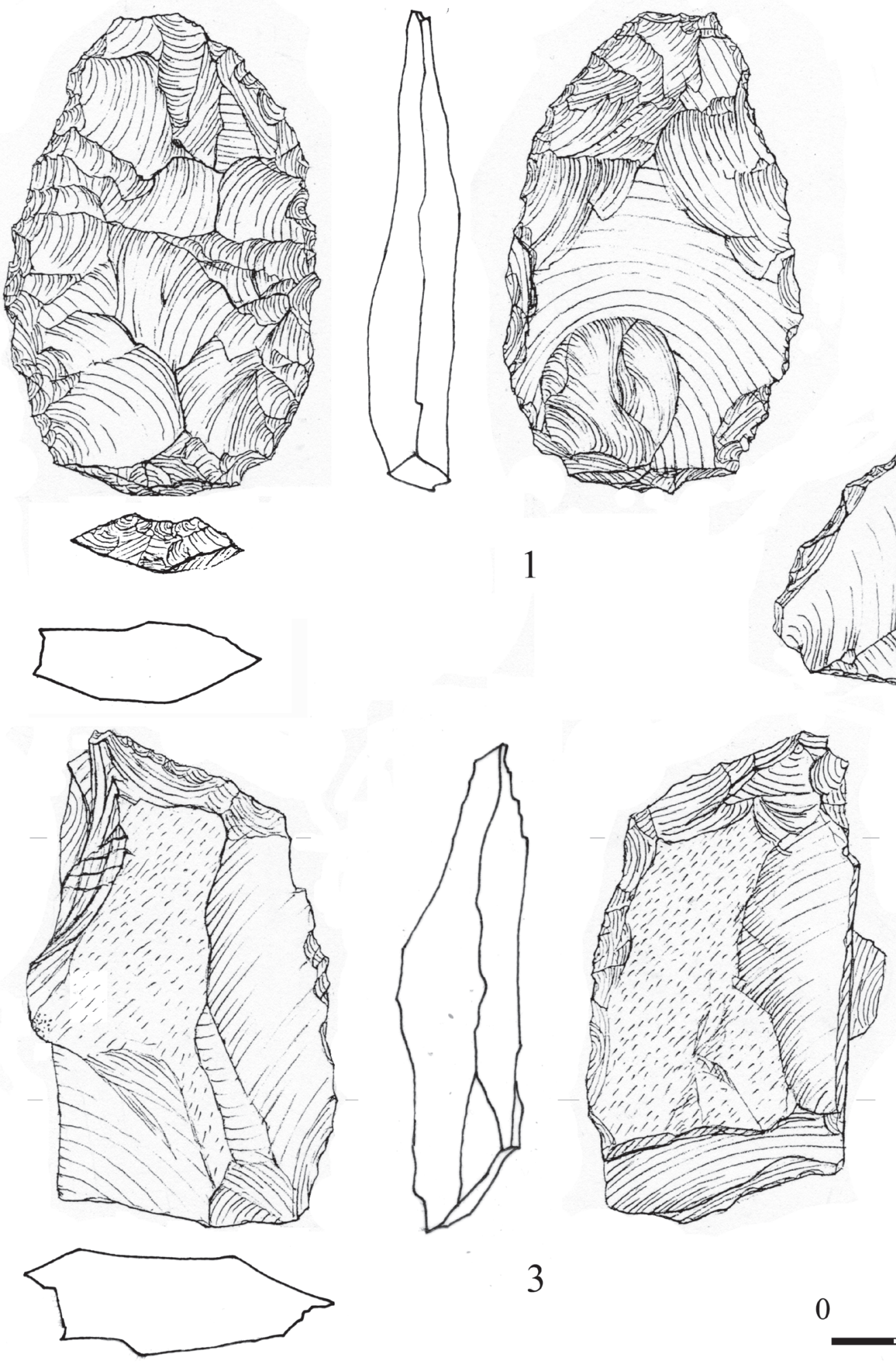

3

Fig. 8. Háromkút cave: artefacts from the site (drawing by K. Nagy) 
tional Museum in 1973. ${ }^{138}$ In connection with the Jankovichian, Hont-Csitár was mentioned along with other assemblages from the open-air sites in Northern Hungary, ${ }^{139}$ but the bifacially worked and Middle Palaeolithic artefacts were added to the Palaeolithic collection only after the death of the excavator in 1996. Regrettably, some tools, published in $1964^{140}$ were found together in the boxes with the lithics of the 1969 excavations, indicating the mixing of the artefacts. ${ }^{141}$ Luckily, the site was successfully re-identified in 2002 by K. Zandler, A. Péntek and A. Markó. This way, in the future it will be possible to organise control excavations on this important site with the aim of clearing the stratigraphy and the chronology of the artefact bearing layer, as well as the typological composition of the lithic assemblage. On the other hand, some new data concerning the cultural classification not only of this site but indirectly also of the Remete Upper cave assemblage is expected.

\section{QUESTIONS OF THE CHRONOLOGY}

The Early Würmian age of the Jankovichian industry, proposed by Gábori-Csánk was based on the mammal biostratigraphy, namely the composition of the faunal assemblages. The recent paleontological evaluations, however, suggest for a more recent age for the layers discussed in this paper, even if the systematic analysis of the faunal assemblage from the Remete Upper and probably the Bivak cave, too, may provide a new biochronological date of the sites.

The archaeological classification of the 'Jankovichian' industry is rather problematic. In 2017 M. PatouMathis and her colleagues seemingly refuting our idea pointed out that the lower layer of the Istállóskő cave does not belong to the Late Middle Palaeolithic Jankovichian industry. ${ }^{142}$ In the same year, one of the co-authors of the same paper, virtually arguing against our observation on the presence of the Moravány type leaf shaped tool in the Jankovich cave, ${ }^{143}$ emphasised that in the Moravány-Dlhá assemblage blades and blade cores, missing from the Jankovich assemblage, are also represented. ${ }^{144}$ However, on the same page Mester accepted that the artefacts found in the upper levels of the Jankovich cave can be dated to the Early Upper Palaeolithic period. ${ }^{145}$

Finally, in a paper published in 2016, three co-authors by M. Patou-Mathis reported the presence of Late Gravettian artefacts from the Szeleta cave. Although in layer 5 asymmetric leaf shaped points attributed to the Jankovichian or Early Szeletian industry were also found, the conclusion, that this assemblage '...can represent a Late Gravettian with leaf points', ${ }^{146}$ suggests that 'Jankovichian' lithics in this layer of the Szeleta cave are found in association with the tools dated to the Middle Upper Palaeolithic.

On the other hand, without attaching great importance of the 13 bifacial pieces excavated in more than 950 cubic meters of sediment in the Szeleta cave, after excluding the bifacial tools wearing pseudo-retouch from the study the central hypothesis by Mester was refuted in this paper, as the majority of the asymmetric leaf shaped tools were found in the upper layers $5^{147}$ and $6 .{ }^{148}$ This way, these pieces are neither characteristic forms of the lower

${ }^{138}$ Including some earlier published pieces: GÁBORI 1964, Fig. XIX.7-14,17.

${ }^{139}$ GÁBORI-CSÁNK 1983, 285; GÁBORI-CSÁNK 1984, 21.

${ }^{140}$ GÁbori 1964, Fig. XIX.1-4,15-16; cf. ZANDLER 2010, Fig. 8.3-5, Fig. 9.1-2.

${ }^{141}$ In fact, the problems with the site and the assemblage started earlier: the locality, first mentioned under the name of HontCsitár is in fact identical with Hont-Babat following the present terminology, but not identical with the site excavated by M. Gábori: GÁBORI-CSÁNK 1958, 60-61, obr. 35; ZANDLER 2010, Fig. 33,1.

${ }^{142}$ Patou-Mathis et al. 2017, 86. - Otherwise, this is a typical example for the straw man argument, as we never classified the given assemblage as Jankovichian: MARKó 2017, 194, fn. 14, 15.

${ }^{143}$ This was, however, suggested by J. Bárta more than fifty years ago: BÁRTA 1960, 310 - cf. HILLEBRAND 1926.

${ }^{144}$ Mester 2017, 86. - In our view, the validity of the typological classification of a single artefact cannot be questioned or refuted by technological arguments based on another much larger as-

Acta Archaeologica Academiae Scientiarum Hungaricae 70, 2019 semblage. Moreover, the differences in the site function, i.e. hunting stand in a cave versus open-air workshop site makes the comparison of the assemblages rather difficult: NEMERGUT 2010, 190-191, 193.

145 'Pour chaque gisement [i. e. both the Jankovich and the Szeleta cave], les pièces de la partie inférieur de la séquence peuvent appartenire à une industrie de Paléolithique moyen (tardif?), tandis que celles de la partie supérieure peuvent être d'âge du Paléolithique supérieur ancien.': MESTER 2017, 86.

${ }^{146}$ LENGYEL et al. 2016, 181.

${ }^{147}$ At least in the side corridor of the Szeleta cave, where artefacts from layer 5 were documented, no important sediment mixture was observed. In our view, the composition of this assemblage undermines the scientific value of the results of the 'technological approach' in the case of the Szeleta and Jankovich caves: MARKó 2016, 24, 27-31.

${ }^{148}$ LENGYEL et al. 2016, 177, Table 5. - As a matter of fact, the numbers of leafpoints given in this table differ from those found in Table 1 and 4 of the same paper, cf. note 40 . 
layers of the Szeleta cave nor do they belong to the Early Szeletian and/or Jankovichian industry. Moreover, following the logic used at the Dzeravá skála assemblage, the 44-46 ka B.P. radiocarbon dates from layer 2 of the Szeleta ${ }^{149}$ cave may imply a Micoquian affiliation, ${ }^{150}$ showing that the asymmetric leaf shaped tools are equally known from the Middle, Early Upper and Middle Upper Palaeolithic layers, and these pieces are not exclusively typical for the Jankovichian and/or Early Szeletian entities.

Earlier we emphasised that in lower layer of the Istállóskő cave, ${ }^{151}$ as well as in the Jankovich and Bivak caves the Middle Palaeolithic type and bifacially manufactured lithic tools are associated with the Aurignacian-type osseous industry, ${ }^{152}$ presenting the typical case of the 'observational contemporaneity'. ${ }^{153}$ Without giving a comprehensive review of the Central European and Balkan sites ${ }^{154}$ we refer to the recently published 36 ka BP radiocarbon age $^{155}$ from layer XI of the Obłazowa cave in the Polish Carpathians, where both the osseous point and refitted fragments of a bifacially manufactured leaf point were excavated in the same layer, relatively far from the disturbed part of 'layer XXII', ${ }^{156}$ i.e. in an in situ position.

Finally, the 35.6 ka B.P. direct date of the chisel of antler from the Pálffy/Dzeravá skála cave ${ }^{157}$ is slightly older than the previously published $31-31.6 \mathrm{ka}$ B.P. dates of the points ${ }^{158}$ from the same site and it seems to be consistent with the above mentioned ages of layer 9 and the uppermost level of layer 11, where bifacial technology is represented by characteristic waste material and a fragment of an osseous point was also excavated. ${ }^{159}$ In our view, the osseous artefacts from the Bivak as well as the Jankovich cave will provide similar radiocarbon ages, dating the osseous artefacts to the Middle Würm, approximately to the same period as the Aurignacian sites.

\section{CONCLUSIONS}

In the $21^{\text {st }}$ century the importance of the Szeleta and the Jankovich caves is found in their role of the Palaeolithic research in Hungary. The history of these sites and the 'Szeletian' and 'Jankovichian' industries clearly show that during the evaluation of the results, the data both from the technical literature and the unpublished research reports were often used selectively. Moreover, instead of systematic analysis, ad hoc arguments, informal fallacies and misstatements were also used during the reasoning. Reasoning and important differences in both the numerical data and the interpretation of the same assemblage are frequently noticed in the papers written by the same authors. The most important problem is, however, that the theories and the general reviews are based on the analysis of single pieces and not on the assemblages. ${ }^{160}$

In the present paper we found that the Bivak cave is the single 'Jankovichian' locality, which was adequately documented using the standards of the age of the excavations. The analysis of the faunal assemblage from the Remete Upper cave may give a solid biochronological background of the archaeological artefacts in the future, however, the field observations concerning the lithic tools are largely missing. Finally, in our view, the recent pub-

${ }^{149}$ HaUCK et al. 2016, Tab. 4.

${ }^{150}$ KAMINSKÁ et al. 2005, 55; HAUCK et al. 2016. - Mester seemingly recognised this when he dated the Early Szeletian from the Szeleta cave to 44-41 cal. B.P., even if in the same paper he sorted the asymmetric pieces from layer 2 to the Early Szeletian assemblage: Mester 2017, 86, cf. Mester 2017, 78.

${ }^{151}$ Mester suggested, that the leaf shaped scraper from the lower ('Aurignacian I') layer of this cave at a distance of 8-10 meters from the trenches where the majority of the bone (in fact: antler) points were documented. This is however, a misleading statement, as in trench VIII lying very close to place of recovery of the bifacial tool five osseous artefacts including two split based points were also excavated from the lower layer: MARKó 2017, 206, 216, Table 1, Fig. 9.3.

${ }^{152}$ MARKó 2011a, 109-110; MARKó 2015, 28.

${ }^{153}$ MARKó 2013b, 199; MARKó 2015, 32. - The conjoined fragments (refit group VII) found in the upper and the lower layer of the Istállóskö cave clearly show the complexity of the site formation and/or the problems with the documentation: MARKÓ 2017, 200, Fig. 2, Table 1 .

${ }^{154}$ MARKó 2013b, 196-197.
${ }^{155}$ LORENEC 2013.

${ }^{156}$ VALDE-NOWAK 2003, Fig. 26, 27,1,6.

${ }^{157}$ DAVIES et al. 2015, Table 8b.

${ }^{158}$ Davies-Hedges 2005, Table 1; Davies et al. 2015, Table $8 \mathrm{~b}, 8 \mathrm{c}$

${ }^{159}$ During the excavations by F. Prošek more than twenty osseous tools were excavated, clearly from the Szeletian layer (in the lower part of the greenish-grey - brownish grey layers 5-11 following the stratigraphy published in 1951 or layer 8 in 1953): PROšEK 1951, 296, 297-298; PROŠEK 1953, 185, 191.

${ }^{160}$ The typical examples are the technological investigations of the leaf shaped implements, which, ultimately illustrate the return of the dichotomy of the leaf shaped implements on one hand and the accompanying industry (Begleitindustrie) on the other one. This rightly criticized approach was typical in the $20^{\text {th }}$ century, see: MESTER 2018, 21 - In agreement with the view expressed earlier by Mester and rejected later without proper argumentation, the leaf shaped implements in themselves are not suitable for archaeological classification: MEsTER 2011, 29; MESTER 2014a, 53. 
lication on the artefacts from the Dzeravá skála cave allows supposing a leafpoint assemblage ('Szeletian') in layer 9 and 11.

Regrettably, the artefacts from the Jankovich cave were excavated almost exclusively without stratigraphic control and some pieces were erroneously attributed to this assemblage. ${ }^{161}$ Besides, a few pieces, collected in some cases as stray finds or without stratigraphic observation and having questionable cultural classification have been incorporated to the Jankovichian. This way, after the review of the assemblages excavated after the World War II in Hungary, it is clear that it was prematurely defined as a separate cultural entity. On the other hand, the use of the term 'Szeletian' should be restricted for the Bükk sites, ${ }^{162}$ where the occurrences of the asymmetrical leaf shaped tools are independent from the chronological or cultural classification of the similar pieces of the Jankovich cave.

From our part, we suggest to the use the term 'leaf shaped industry' (Blattspitzenindustrie) ${ }^{163}$ for the diverse lithic assemblages with Middle Palaeolithic elements from the cave sites in the Transdanubia and in the Bükk Mountains, ${ }^{164}$ as well as for the recently excavated assemblages in the Cserhát Mountains. Beside the new excavations of the open-air sites and possibly, in the Istállóskő cave ${ }^{165}$ the next step in this research can be the investigation of the 'modern traits' known from the assemblages: the intense use of the extralocal raw materials on the Cserhát sites and the presence of the osseous industry in the cave localities.

\section{REFERENCES}

BÁRTA 1960 J. BÁRTA: K problému listovitých hrotov typu Moravany-Dlhá (Autour du problème des pointes foliacées du type Moravany-Dlhá). S1A 8/2 (1960) 295-324.

BIRÓ 1984

BÍRÓ 1984

BIRÓ 2002

Bolus 2004

BOLUS-RÜCK 2000

BOSINSKI 2000-2001

CHABAI 2003

DAvies-Hedges 2005

DAVIES et al. 2015

DIENES 1968

Dobosi 2006

DoBOSI-VÖRÖs 1979

$=$ K. BIRó: Distribution of obsidian from the Carpathian sources on Central European Palaeolithic and Mesolithic sites. AAC 23 (1984) 5-42.

= K. BíRó: Őskőkori és őskori pattintott kőeszközök nyersanyagának forrásai (Sources of lithic raw materials for chipped implements in Hungary). ArchÉrt 111/1 (1984) 42-52.

= K. BIRó: New data on the utilisation of Buda hornstone in the early Bronze Age. BudRég 36 (2002) 131-143.

= M. BoLus: Der Übergang vom Mittel- zum Jungpaläolithikum in Europa. Eine Bestandsaufnahme unter besonderer Berücksichtigung Mitteleuropas. Germania 82 (2004) 1-54.

= K. Bolus-O. RücK: Eine Blattspitze aus Wittislingen, Lkr. Dillingen a. d. Donau (Bayern). Zur südwestlichen Verbreitungsgrenze spätmittelpaläolithischer Blattspitzeninventare. AKorr 30 (2000) $165-172$.

= G. BosinsKI: El paleolítico medio en Europa Central. Zephyrus 53-54 (2000-2001) 79-142.

$=\mathrm{V}$. CHABAI: The chronological and industrial variability of the Middle to Upper Paleolithic transition in Eastern Europe. In: The Chronology of the Aurignacian and of the Transitional Technocomplexes Dating, Stratigraphies, Cultural Implications. Eds: J. Zilhăo, F. d'Errico. Trabalhos de arqueologia 3. Lisboa 2003, 71-86.

=W. Davies-R. Hedges: Dating the Middle-to-Upper Palaeolithic transition: a new chronometric framework. In: Pleistocene Environments and Archaeology of the Dzeravá Skala Cave, Lesser Carpathians, Slovakia. Eds: L. Kaminská, J. K. Kozłowksi, J. A. Svoboda. Kraków 2005, 59-66.

=W. DAVIES-D. WhITE-M. LewIS-C. STRINGER: Evaluating the transitional mosaic: frameworks of change from Neanderthals to Homo sapiens in eastern Europe. Quaternary Science Reviews 118 (2015) 211-242.

= I. DiEnEs: Examen pétrographique de l'industrie. In: La station du Palélothique Moyen d'Érd, Hongrie. Ed.: V. Gábori-Csánk. Budapest 1968, 111-114.

= V. Dobosi: Lovas (Hungary) ochre mine reconsidered. In: Stone Age-Mining Age. Hrsg.: G. Körlin, G. Weisgerber. Der Anschnitt, Beiheft $19=$ Veröffentlichungen aus dem Deutschen BergbauMuseum 148. Bochum 2006, 29-36.

$=$ V. Dobosi-I. VöRös: Data to the evaluation of the finds assemblage of the Palaeolithic paint mine at Lovas. FolArch 30 (1979) 7-26.

${ }^{161}$ MARKÓ 2013a, 17, note 29.

162 VÉrtes 1968; Freund 1968; GÁbori 1968; MARKó

2016,32 .

${ }^{163}$ Bolus-RÜCK 2000, 168; BosInSKi 2000-2001, 126133; Bolus 2004, 20 .

${ }^{164}$ Including a part of the assemblage from the Szeleta cave, however, keeping in mind that the lithics, excavated in the upper Acta Archaeologica Academiae Scientiarum Hungaricae 70, 2019 layers of this cave are most probably dated to the Middle Upper Palaeolithic: LENGYEL et al 2016.

${ }^{165}$ MARKó 2017, 215-216.

${ }^{166}$ The original photograph is stored in the Archives of the Budapest History Museum under the number of H_1540-2004. We are grateful for the friendly help of the colleagues working for the Budapest History Museum. 
DOBOSI-VÖRÖS 1986

DOBOSI-VÖRÖS 1994

FOLTYN 2003

FÖLDVÁRY 1929

FREUND 1968

GÁBORI 1953

GÁBORI 1964

GÁBORI 1968

GÁBORI 1976

GÁBORI 1981

GÁBORI-CsÁNK 1956

GÁBORI-CsÁNK 1958

G. CsÁNK 1970

G. CSÁNK 1971

GÁBORINÉ CsÁNK 1973

GÁBORI-CsÁNK 1990

GÁBORI-CsÁNK 1993

HAUCK et al. 2016

HiLLEBRAND 1926

HILLEBRAND 1935

JÁNOSSY 1977

JÁNOSSY et al. 1957

KADIĆ 1934

Kadić-KretzoI 1926-1927

KAMINSKÁ 2014

KAMINSKÁ et al. 2005

KRETZOI 1954

LENGYEL et al. 2016

LisTER-STUART 2019

LORENC 2013
= V. DoBosI-I. VöRös: Chronological revision of the Pilisszántó-Rockshelter II. FolArch 37 (1986) 25-45.

= V. DoBosI-I. VöRös: Material and chronological revision of the Kiskevély cave. FolArch 42 (1994) 9-50.

= E. Foltyn: Uwagi o osadnictwie kultur z ostrzami liściowatymi na północ od łuku Karpat (Bemerkungen zur Besiedlung der Blattspitzenkulturen nördlich des Karpatenbogens). PrzA 51 (2003) $5-48$.

= A. FöLDVÁRY: Adatok a bia-tétnyi plató oligocén-miocén rétegeinek stratigafiájához (Beiträge zur Stratigraphie der Oligocen-Miocen-Schichten des Plateaus von Bia-Tétény). AnnHN 26 (1929) 35-59.

= G. Freund: Comments [on the paper by K. Valoch]. CurrAnt 9 (1968) 372.

= M. GÁBORI: Solûtrejsaâ kul'tura Vengrii (Le Solutréen en Hongrie). ActaArchHung 3 (1953) 1-68.

= M. GÁBORI: A késői paleolitikum Magyarországon (The Late Paleolithic in Hungary). RégTan 3. Budapest 1964.

= M. GÁBORI: Comments [on the paper by K. Valoch]. CurrAnt 9 (1968) 372-373.

= M. GÁBORI: Les civilisations du Paléolithique Moyen entre les Alpes et l'Oural. Esquisse historique. Budapest 1976.

= M. GÁBORI: Az ősember korának kutatása Magyarországon (1969-1980) (The research of the Prehistoric humans in Hungary, 1969-1980). MTAK(II) 30 (1981) 91-109.

= V. GÁBori-CsánK: Megjegyzések a szlovákiai szeletien kérdéséhez (Beiträge zur Frage des slowakischen Szeletien). ArchÉrt 83 (1956) 78-83.

= V. GÁBORI-CSÁNK: Neue paläolithische Funde im Eipel-Tal. AR 10 (1958) 55-61.

= V. G. CsÁNK: Budapest II., Máriaremete, Obere Höhle. ArchÉrt 97 (1970) 306.

= V. G. CsÁnK: Budapest II., Máriaremete, Obere Höhle. ArchÉrt 98 (1971) 265

= V. GÁBORINÉ CsÁNK: Máriaremete - Felső barlang. BudRég 23 (1973) 257.

= V. GÁBorI-CsÁNK: Le Jankovichien en Hongrie de l'Ouest. In: Paléolithique moyen récent et Paléolithique supérieur ancien en Europe. Colloque international de Nemours, 9-11 mai 1988. Sous la dir. de C. Farizy. Mémoires du Musée de Préhistoire d'Ile-de-France 3. Nemours 1990, 97-102.

= V. GÁBorI-CsÁNK: Le Jankovichien. Une civilisation paléolithique en Hongrie. ERAUL 53. Liège 1993.

= T. C. Hauck-J. Rethemeyer-P. Rentzel-P. Schulte-S. Heinze-A. Ringer-J. Richter-W. ChuF. LEHMKUHL-O. VogeLs: Neanderthals or early modern humans? A revised chronology and geoarchaeological study of the Szeletian sequence in Szeleta cave (Kom. Borsod-Abaúj-Zemplén) in Hungary. AKorr 46 (2016) 271-290.

= E. VON HILlEBRAND: Über neuere Funde aus dem ungarländischen Paläolithikum. Die Eiszeit 3 (1926) 3-5.

= J. HillebRAND: Magyarország őskőkora - Die ältere Steinzeit Ungarns. ArchHung 17. Budapest 1935.

= D. JÁNOSSY: A magyarországi pleisztocén tagolása gerinces faunák alapján (The Division of the Pleistocene after the Vertebrate Faunas in Hungary). Budapest 1977.

= D. JÁNOSSY-S. KRETZOI-VARRÓK-M. HERRMANN-L. VÉRTES: Forschungen in der Bivakhöhle, Ungarn. Eiszeitalter und Gegenwart 8 (1957) 18-36.

= O. KADIĆ: Der Mensch zur Eiszeit in Ungarn. A Magyar Királyi Földtani Intézet Évkönyve 30/1. Budapest 1934.

= O. KADIĆ-M. KRETZOI: Előzetes jelentés a Csákvári sziklaüregben végzett ásatásokról - Vorläufiger Bericht über die Ausgrabungen in der Csákvárer Höhlung. Barlangkutatás 14-15 (1926-1927) 1-19, 40-60.

= L. KAMINSKÁ: Staré Slovensko. 2.: Paleolit a mezolit (Ancient Slovakia. 2: Palaeolithic and Mesolithic). Nitra 2014.

= L. KaminskÁ-J. K. KozŁowski-J. A. Svoboda: Sequence of Palaeolithic occupations. In: Pleistocene Environments and Archaeology of the Dzeravá Skala Cave, Lesser Carpathians, Slovakia. Eds: L. Kaminská, J. K. Kozłowksi, J. A. Svoboda. Kraków 2005, 7-58.

= M. KretzoI: Befejező jelentés a Csákvári barlang őslénytani feltárásáról (Rapport final des fouilles dans le grotte de Csákvár). MÁFIJ 1952 (1954) 37-55.

= Gy. Lengyel-Zs. Mester-P. SzolyÁk: The Late Gravettian and the Szeleta Cave, Northeast Hungary. Quaternary International 406 (2016) 174-183.

= A. M. Lister-A. J. STUART: The extinction of the giant deer Megaloceros giganteus (Blumenbach): New radiocarbon evidence. Quaternary International (2019) in press.

= M. LORENC: Radiocarbon ages of bones from Vistulian (Weichselian) cave deposits in Poland and their stratigraphy. Acta Geologica Polonica 63 (2013) 399-424. 
MARKÓ 2007

MARKÓ 2011a

MARKÓ 2011b

MARKÓ 2012

MARKÓ 2013a

MARKÓ 2013b

MARKÓ 2015

MARKÓ 2016

MARKÓ 2017

MARKÓ-KÁZMÉR 2004

MARKS-MonigAL 2000

Mester 2000

Mester 2010

MESTER 2011

Mester 2014a

Mester 2014b

Mester 2017

Mester 2018

MÉSZÁROS-VÉRTES 1954

MiHAILOVIĆ-ZoRBIĆ 2017

NeMERGUT 2010

NIGST 2012

Patou-MATHIS 2000

Patou-Mathis 2002

PATOU-MATHIS et al. 2017
= A. MARKó: Preliminary report on the excavations of the Middle Palaeolithic site Vanyarc Szlovácka-dolina. ComArchHung 2007, 5-18.

= A. MARKó: Raw material use at the Middle Palaeolithic site of Vanyarc (Northern Hungary). Praehistoria 9-10 (2008-2009) [2011] 183-194.

= A. MARKó: A kései középső paleolitikum csontipara a Kárpát-medencében (The osseous industry of the Late Middle Palaeolithic period in the Carpathian Basin). ArchÉrt 136 (2011) 95-113.

= A. MARKó: Középső-paleolitikus leletegyüttesek Vanyarc környékén (Middle Palaeolithic Assemblages from the Environs of Vanyarc, Northern Hungary). [Manuscript, Unpublished PhD thesis] Budapest 2012

= A. MARKó: On the Middle Palaeolithic industry of the Jankovich cave (Northeastern Transdanubia). ArchÉrt 138 (2013) 7-28.

= A. MARKó: Leaf-shaped lithic and osseous tools from old excavated cave sites: demonstrating associations. In: The Sound of Bones. Proceedings of the 8th meeting of the ICAZ Worked Bone Reasearch Group in Salzburg 2011. Ed.: F. Lang. Salzburg 2013, 191-202.

= A. MARKó: Istállóskő revisited: lithic artefacts and assemblages, sixty years after. ActaArchHung 66 (2015) 6-38.

= A. MARKó: Considerations on the lithic assemblages from the Szeleta cave. ComArchHung 2016, $5-44$.

= A. MARKó: Istállóskő revisited: the osseous artefacts from the lower layer. ActaArchHung 68 (2017) 193-218.

= A. MARKó-M. KÁZMÉR: The use of nummulitic chert in the Middle Palaeolithic in Hungary. In: Topical Issues of the Research of Middle Palaeolithic Period in Central Europe. Eds: É. Fülöp, J. Cseh. Tatabánya 2004, 53-64.

= A. E. Marks-K. Monigal: The Middle to Upper Palaeolithic interface at Buran-Kaya-III, Eastern Crimea. In: Neanderthals and Modern Humans - Discussing the Transition: Central and Eastern Europe from 50.000 - 30.000 B.P. Eds: J. Orschiedt, G-Ch. Weniger. Wissenschaftliche Schriften des Neanderthal Museums 2. Mettmann 2000, 212-226.

= Zs. MEster: Apparition du Jankovichien au sud de la Montagne de Bükk (Hongrie). In: À la recherche de l'Homme Préhistorique. Volume commémoratif de Miklós Gábori et de Veronika Gábori-Csánk. Dir.: Zs. Mester, Á. Ringer. ERAUL 95. Liège 2000, 247-255.

= Zs. MESTER: Technological analysis of Szeletian bifacial points from Szeleta cave (Hungary). Human Evolution 25/1-2 (2010) 107-123.

= Zs. MEster: A magyarországi középső és felső paleolitikum bifaciális levéleszközeinek technológiája (Technologie des pièces foliacées bifaces du Paléolithique moyen et supérieur de la Hongrie). In: Emlékkönyv Violának. Tanulmányok T. Dobosi Viola tiszteletére - Papers in Honour of Viola T. Dobosi. Eds: K. Biró, A. Markó. Budapest 2011, 15-41.

= Zs. MESTER: Technologie des pièces foliacées bifaces du Paléolithique moyen et supérieur de la Hongrie. In: Aeolian Scripts - New Ideas on the Lithic World. Studies in honour of Viola T. Dobosi. Eds: K. Biró, A. Markó, K. Bajnok. IPH 13. Budapest 2014, 41-62.

= Zs. Mester: Le Szélétien. In: Néandertal / Cro-Magnon - La Rencontre. Ed: M. Otte. Arles 2014, $149-188$.

= Zs. Mester: Considerations sur le Szélétien en Hongrie: la relation du Jankovichien au Szélétien Ancien. Anthropologie (Brno) 55 (2017) 75-92.

= Zs. MEster: The problems of the Szeletian as seen from Hungary. Recherches Archéologiques 9 (2017) [2018] 19-48.

= Gy. MÉszÁros-L. VÉRTEs: A paint mine from the Early Upper Palaeolithic Age near Lovas (Hungary, County Veszprém). ActaArchHung 5 (1954) 1-34.

= D. D. MiHAILOvić-B. N. ZorbIĆ: Risovača i problem regionalne diferencijacije sredn'opaleolitskih industrija sa listolikim sil'cima (Risovača and the problem of the regional differentiation of the Middle Palaeolithic leaf-point industries). ZNM 23/1 (2017) 37-55.

= A. NemERGUT: Paleolitické osídlenie v Moravanoch nad Váhom-Dlhej. Výsledky výskumov Juraja Bártu z rokov 1963 a 1990 (Palaeolithic settlement in Moravany nad Váhom-Dlhá. Results of Juraj Bárta's excavations in 1963 and 1990). S1A 58/2 (2010) 183-206.

= P. Nigst: The Early Upper Palaeolithic of the Middle Danube Region. Leiden 2012

= M. PATOU-MATHIS: Neanderthal subsistence behaviours in Europe. International Journal of Osteoarchaeology 10 (2000) 379-395.

= M. Patou-Mathis: Nouvelle analyse du matériel osseux du site de Lovas (Hongrie). Praehistoria 3 (2002) 161-175.

= M. Patou-Mathis-C. Vercoutère-Gy. Lengyel-P. Szolyák-Zs. Mester: New interpretation of the Upper Palaeolithic human occupations at the Istállóskő cave (Bükk Mountains, Hungary). Eurasian Prehistory 13/1-2 (2017) 77-90. 
PÉAN et al. 2013

PRoŠEK 1953

REGŐS-RINGER 2003

SAJÓ et al. 2015

VALDE-NOWAK 2003

VÉRTES 1951

VÉRTES 1955a

VÉRTES 1955b

VÉRTES 1962

VÉRTES 1964

VÉRTES 1965

VÉRTES 1968

M. VIRÁG 1995

VÖRÖS 2010

ZANDLER 2010

ZALIZNYAK-BELENKO 2009
= S. PÉan-S. Puaud-L. Crépin-S. Prat-A. Quiles-J. van der Plicht-H. Valladas-A. J StuartD. G Drucker-M. Patou-Mathis-F. LanoË-A. Yanevich: The Middle to Upper Paleolithic sequence of Buran-Kaya III (Crimea, Ukraine): new stratigraphic, paleoenvironmental, and chronological results. In: Proceedings of the 21 st International Radiocarbon Conference held in Paris, France, 9-13 July 2012. Eds: A. J. T. Jull, C. Hatté. Radiocarbon 55/2-3. Tucson 2013, 1454-1469.

= Fr. ProšEK: Szeletian na Slovensku (Le Szeletien en Slovaquie). S1A 1 (1953) 133-194.

= J. REGŐS-Á. RINGER: Három-kúti-barlang (Három-kút cave). In: Magyarország fokozottan védett barlangjai. Ed.: K. Székely. Budapest, 2003, 163-165.

I. E. SAJÓ-J. KovÁcs-K. E. Fitzsimmons-V. JÁGER-Gy. LENGYEL-B. Viola-S. TALAMO-J.-J. Hublin: Core-Shell Processing of Natural Pigment: Upper Palaeolithic Red Ochre from Lovas, Hungary. PLoS ONE July 2015 DOI:10.1371/journal.pone.0131762

= P. VALDE-NowAK: Upper Palaeolithic sequence. In: Obłazowa Cave-Human Activity, Stratigraphy and Palaeoenvironment. Eds: P. Valde-Nowak, A. Nadachowski, T. Madeyska. Kraków 2003, 44-68. = L. VÉRTES: L'abri II de Pilisszántó. AnnHN 42 (1951) 223-231.

= L. VÉRTES: Paläolithische Kulturen des Würm I/II Interstadials in Ungarn. ActaArchHung 5 (1955) 261-278.

= L. VÉRTES: Les conditions de l'interstadial Würmien I/II Hongrois élucidées par l'examen des remplissages de grottes. ActaGeolHung 3 (1955) 393-407.

= L. VÉRTES: Altsteinzeitfunde aus der Csákvárer Höhle. MAGW 92 (1962) 278-284.

= L. VÉRTES: Die Ausgrabung und die archäologischen Funde. In: Tata - Eine mittelpaläolithische Travertin-Siedlung in Ungarn. Hrsg.: L. Vértes. ArchHung 43. Budapest 1964, 133-249.

= L. VÉRTES: Az őskőkor és az átmeneti kőkor emlékei Magyarországon (Records of the Palaeolithic and Mesolithic in Hungary). A magyar régészet kézikönyve 1. Budapest 1965.

= L. VÉRTES: Szeleta-Symposium in Ungarn, 4.-11. September 1966. Quartär 19 (1968) 381-390.

= Zs. M. VIRÁG: Die Hochkupferzeit in der Umgebung von Budapest und in NO-Transdanubien (das Ludanice-Problem). ActaArchHung 47 (1995) 61-94.

= I. VöRÖs: Pézsmatulok (Ovibos pallantis H. Smith) koponyalelet a zebegényi epigravetti vadásztelepen (Musk-ox (Ovibos pallantis H. Smith) cranial from the Epigravettian hunter's campsite at Zebegény). FolArch 54 (2008-2010) 39-55.

= K. ZANDLER: Paleolit telet Hont-Csitáron (Palaeolithic site at Hont-Csitár). In: Régről kell kezdenünk. Studia archaeologica in honorem Pauli Patay - Régészeti tanulmányok Nógrád megyéből Patay Pál tiszteletére. Eds: Sz. Guba, K. Tankó. Szécsény 2010, 23-49.

= L. L. ZALIZNYAK-M. M. BELENKO: Stoânka Vis' rannoi pori verhn'ogo paleolitu na Kirovogradščini [Site at Vish and the earlier phase of the Upper Palaeolithic in the Kirovohrad region]. Arheologiâ (Kiiv) 3 (2009) 35-44.

Open Access. This is an open-access article distributed under the terms of the Creative Commons Attribution 4.0 International License (https://creativecommons.org/licenses/by/4.0), which permits unrestricted use, distribution, and reproduction in any medium, provided the original author and source are credited, a link to the CC License is provided, and changes - if any - are indicated. (SID_1) 
